\section{Pacific Northwest}

National Laboratory

Operated by Battelle for the

U.S. Department of Energy

\title{
Removal of ${ }_{137}$ Cs from Dissolved Hanford Tank Saltcake by Treatment with IE-911
}

B. M. Rapko

S. I. Sinkov

T. G. Levitskaia

December 2003

Prepared for the U.S. Department of Energy under Contract DE-AC06-76RL01830 


\title{
DISCLAIMER
}

This report was prepared as an account of work sponsored by an agency of the United States Government. Neither the United States Government nor any agency thereof, nor Battelle Memorial Institute, nor any of their employees, makes any warranty, express or implied, or assumes any legal liability or responsibility for the accuracy, completeness, or usefulness of any information, apparatus, product, or process disclosed, or represents that its use would not infringe privately owned rights. Reference herein to any specific commercial product, process, or service by trade name, trademark, manufacturer, or otherwise does not necessarily constitute or imply its endorsement, recommendation, or favoring by the United States Government or any agency thereof, or Battelle Memorial Institute. The views and opinions of authors expressed herein do not necessarily state or reflect those of the United States Government or any agency thereof.

\author{
PACIFIC NORTHWEST NATIONAL LABORATORY \\ operated by \\ BATTELLE \\ for the \\ UNITED STATES DEPARTMENT OF ENERGY \\ under Contract DE-AC06-76RL01830
}

This document was printed on recycled paper. 


\section{Removal of ${ }^{137}$ Cs from Dissolved Hanford Tank Saltcake by Treatment with IE-911}

B. M. Rapko

S. I. Sinkov

T. G. Levitskaia

December 2003

Prepared for the U.S. Department of Energy

under Contract DE-AC06-76RL01830

Pacific Northwest National Laboratory

Richland, WA 99352 


\section{Summary}

The U.S. Department of Energy's Richland Operations Office plans to accelerate the cleanup of the Hanford Site. Testing new technology for the accelerated cleanup will require dissolved saltcake from single-shell tanks. However, the ${ }^{137} \mathrm{Cs}$ will need to be removed from the saltcake to alleviate radiation hazards. A saltcake composite constructed from archived samples from Hanford Site single-shell tanks 241-S-101, 241-S-109, 241-S-110, 241-S-111, 241-U-106, and 241-U-109 was dissolved in water, adjusted to $5 \mathrm{M}$ Na, and transferred from the 222-S Laboratory to the Radiochemical Processing Laboratory (RPL). At the RPL, the approximately 5.5 liters of solution was passed through a 0.2-micron polyethersulfone filter, collected, and homogenized. The filtered solution then was passed through an ion exchange column containing approximately $150 \mathrm{~mL}$ IONSIV ${ }^{\circledR}$ IE-911, an engineered form of crystalline silicotitanate available from UOP, at approximately $200 \mathrm{~mL} /$ hour in a continuous operation until all of the feed solution had been run through the column. An analysis of the ${ }^{137} \mathrm{Cs}$ concentrations in the initial feed solution and combined column effluent indicates that $>99.999$ percent of the Cs in the feed solution was removed by this operation. Table S1 summarizes the available analytical information, including all specifically requested analytes of concern. In this table, if the analytes are present in less than the requested minimum reportable quantity, even if detected and quantified, then the "less than" value is applied.

This revision became necessary upon the discovery of a quality assurance failure in the standards concentrations used in the ${ }^{99} \mathrm{Tc}$ (by inductively coupled plasma-mass spectrometry [ICP-MS]) and pertechnetate analyses. The source of the failure, a discrepancy between the standards concentrations used to calibrate the instruments and the true value, had a projected impact of making the analyses reported in the initial report about 25\% lower than their "true” value. Because of a concern about the possibility of changes in the pertechnetate/total ${ }^{99}$ Tc ratio in these materials as a function of time, and because of the impossibility of definitively knowing the standard's true concentration at the time they were used, it was decided to reanalyze the Cs-depleted material for total ${ }^{99} \mathrm{Tc}$ (by ICP-MS) and pertechnetate. Tables S1, 3.1, and 3.8 now report the revised values. In addition, the discussion in Section 3.4.8 now reports the corrected pertechnetate results and Section 3.4.13 the revised ${ }^{99}$ Tc results. In summary, the pertechnetate/total ${ }^{99} \mathrm{Tc}$ ratios appear unchanged from the original analyses, and the revised numbers are in generally good agreement with the anticipated changes. In a final change from the earlier report, the significant figures reported for the inductively coupled plasma-atomic emission spectroscopy analyses have been updated in Tables S1 and 3.3. 
Table S1. Analysis of Initial and Cs-Depleted Feed Solutions

\begin{tabular}{|c|c|c|c|c|}
\hline \multirow[b]{2}{*}{ Analyte } & \multirow[b]{2}{*}{ Method } & \multirow[b]{2}{*}{ Units } & Cs-depleted Feed Solution & Initial Feed Solution \\
\hline & & & Average (SD) & Average (SD) \\
\hline$A l$ & ICP-AES & $\mu \mathrm{g} / \mathrm{mL}$ & $5600(78)$ & $5680(54)$ \\
\hline$B a$ & ICP-AES & $\mu \mathrm{g} / \mathrm{mL}$ & $<2.3$ & $<2.3$ \\
\hline $\mathrm{Ca}$ & ICP-AES & $\mu \mathrm{g} / \mathrm{mL}$ & $<150$ & $<150$ \\
\hline $\mathrm{Ce}$ & ICP-AES & $\mu \mathrm{g} / \mathrm{mL}$ & $<2.3$ & $<2.3$ \\
\hline$C d$ & ICP-AES & $\mu \mathrm{g} / \mathrm{mL}$ & $<7.5$ & $<7.5$ \\
\hline $\mathrm{Cr}$ & ICP-AES & $\mu \mathrm{g} / \mathrm{mL}$ & 965(8) & $990(7)$ \\
\hline Cs & ICP-MS & $\mathrm{M}$ & ND & $1.90(0.01) \mathrm{E}-05$ \\
\hline $\mathrm{Fe}$ & ICP-AES & $\mu \mathrm{g} / \mathrm{mL}$ & $<150$ & $<150$ \\
\hline K & ICP-AES & $\mu \mathrm{g} / \mathrm{mL}$ & $353(28)$ & $410(22)$ \\
\hline $\mathrm{Hg}$ & Cold Vapor AA & $\mu \mathrm{g} / \mathrm{mL}$ & $<1.5$ & NA \\
\hline$L a$ & ICP-AES & $\mu \mathrm{g} / \mathrm{mL}$ & $<35$ & $<35$ \\
\hline $\mathrm{Na}$ & ICP-AES & $\mu \mathrm{g} / \mathrm{mL}$ & $117000(2500)$ & $118000(500)$ \\
\hline $\mathrm{Ni}$ & ICP-AES & $\mu \mathrm{g} / \mathrm{mL}$ & $37(0.2)$ & $39(0.2)$ \\
\hline$P$ & ICP-AES & $\mu \mathrm{g} / \mathrm{mL}$ & $1650(48)$ & $1800(17)$ \\
\hline$P b$ & ICP-AES & $\mu \mathrm{g} / \mathrm{mL}$ & $<300$ & $<300$ \\
\hline $\mathrm{Si}$ & ICP-AES & $\mu \mathrm{g} / \mathrm{mL}$ & $111(12)$ & $110(14)$ \\
\hline$U$ & ICP-AES & $\mu \mathrm{g} / \mathrm{mL}$ & $<600$ & $<600$ \\
\hline $\bar{U}$ & LF & $\mu \mathrm{g} / \mathrm{mL}$ & $<780$ & NA \\
\hline TOC & $\begin{array}{c}\text { Furnace } \\
\text { Oxidation }\end{array}$ & $\mu \mathrm{g} \mathrm{C} / \mathrm{mL}$ & 5370 & NA \\
\hline TIC & $\begin{array}{c}\text { Furnace } \\
\text { Oxidation }\end{array}$ & $\mu \mathrm{g} \mathrm{C} / \mathrm{mL}$ & 4420 & NA \\
\hline TOC & $\begin{array}{c}\text { Hot Persulfate } \\
\text { Oxidation }\end{array}$ & $\mu \mathrm{g} \mathrm{C} / \mathrm{mL}$ & 2800 & NA \\
\hline TIC & $\begin{array}{c}\text { Hot Persulfate } \\
\text { Oxidation }\end{array}$ & $\mu \mathrm{g} \mathrm{C} / \mathrm{mL}$ & 6400 & NA \\
\hline $\mathrm{Cl}$ & IC & $\mu \mathrm{g} / \mathrm{mL}$ & $1470(30)$ & NA \\
\hline$F$ & IC & $\mu \mathrm{g} / \mathrm{mL}$ & $349(5)$ & NA \\
\hline $\mathrm{NO}_{3}$ & IC & $\mu \mathrm{g} / \mathrm{mL}$ & $151000(1150)$ & NA \\
\hline $\mathrm{NO}_{3}$ & $U V-$-vis $^{(a)}$ & $\mu \mathrm{g} / \mathrm{mL}$ & 170000 & NA \\
\hline $\mathrm{NO}_{2}$ & IC & $\mu \mathrm{g} / \mathrm{mL}$ & $19000(200)$ & NA \\
\hline $\mathrm{NO}_{2}$ & UV-vis ${ }^{(a)}$ & $\mu \mathrm{g} / \mathrm{mL}$ & 21900 & NA \\
\hline $\mathrm{PO}_{4}$ & IC & $\mu \mathrm{g} / \mathrm{mL}$ & $<2500$ (as P) & NA \\
\hline $\mathrm{SO}_{4}$ & IC & $\mu \mathrm{g} / \mathrm{mL}$ & $8950(21)$ & NA \\
\hline $\mathrm{CrO}_{4}$ & UV-vis ${ }^{(a)}$ & $\mu \mathrm{g} / \mathrm{mL}$ & $2160(967 \mu \mathrm{g} \mathrm{Cr} / \mathrm{mL})$ & NA \\
\hline $\mathrm{C}_{2} \mathrm{O}_{4}$ & IC & $\mu \mathrm{g} / \mathrm{mL}$ & $1250(565)$ & NA \\
\hline${ }^{60} \mathrm{Co}$ & $\gamma$-spectroscopy & $\mu \mathrm{Ci} / \mathrm{mL}$ & $0.00681(0.00025)$ & $0.00562(0.00079)$ \\
\hline${ }^{79} \mathrm{Se}$ & Sep/LSC & $\mu \mathrm{Ci} / \mathrm{mL}$ & $<9 \mathrm{E}-05$ & NA \\
\hline${ }^{90} \mathrm{Sr}$ & Sep/LSC & $\mu \mathrm{Ci} / \mathrm{mL}$ & $<0.15$ & NA \\
\hline${ }^{99} T C$ & ICP-MS & $\mu \mathrm{Ci} / \mathrm{mL}$ & $0.0542(0.0016)$ & $0.0399(0.0003)^{*}$ \\
\hline
\end{tabular}


Table S1 (cont'd)

\begin{tabular}{|c|c|c|c|c|}
\hline \multirow[b]{2}{*}{ Analyte } & \multirow[b]{2}{*}{ Method } & \multirow[b]{2}{*}{ Units } & Cs-depleted Feed Solution & Initial Feed Solution \\
\hline & & & Average (SD) & Average (SD) \\
\hline${ }^{99} \mathrm{TcO}_{4}$ & Sep/LSC & $\mu \mathrm{Ci} / \mathrm{mL}$ & $0.0422(0.0029)$ & NA \\
\hline${ }^{126} \mathrm{Sn} /{ }^{126} \mathrm{Sb}$ & $\gamma$-spectroscopy & $\mu \mathrm{Ci} / \mathrm{mL}$ & $<6 \mathrm{E}-03$ & ND \\
\hline${ }^{127} I$ & ICP-MS & $\mu \mathrm{g} / \mathrm{L}$ & $899(22)$ & NA \\
\hline${ }^{129} I$ & ICP-MS & $\mu \mathrm{Ci} / \mathrm{mL}$ & $0.0000585(0.0000024)$ & NA \\
\hline${ }^{133} \mathrm{Cs}$ & ICP-MS & $\mu \mathrm{g} / \mathrm{L}$ & $<0.013^{(\mathrm{b})}$ & $2530(17)$ \\
\hline${ }^{137} \mathrm{Cs}$ & ICP-MS & $\mu \mathrm{Ci} / \mathrm{mL}$ & ND & $18.5^{(\mathrm{c})}$ \\
\hline${ }^{137} \mathrm{Cs}$ & $\gamma$-spectroscopy & $\mu \mathrm{Ci} / \mathrm{mL}$ & $0.00121(0.00020)^{(d)}$ & $46.6(0.4)$ \\
\hline${ }^{152} \mathrm{Eu}$ & $\gamma$-spectroscopy & $\mu \mathrm{Ci} / \mathrm{mL}$ & $0.000171(0.000006)$ & ND \\
\hline${ }^{154} E u$ & $\gamma$-spectroscopy & $\mu \mathrm{Ci} / \mathrm{mL}$ & $0.00889(0.00039)$ & ND \\
\hline${ }^{155} \mathrm{Eu}$ & $\gamma$-spectroscopy & $\mu \mathrm{Ci} / \mathrm{mL}$ & $0.00466(0.00029)$ & ND \\
\hline${ }^{237} \mathrm{~Np}$ & ICP-MS & $\mu \mathrm{Ci} / \mathrm{mL}$ & $<0.027$ & NA \\
\hline${ }^{238} \mathrm{Pu}$ & $\alpha$-spectroscopy & $\mu \mathrm{Ci} / \mathrm{mL}$ & $<0.01$ & NA \\
\hline${ }^{239} \mathrm{Pu}$ & ICP-MS & $\mu \mathrm{Ci} / \mathrm{mL}$ & $<3.0 \mathrm{E}-02$ & NA \\
\hline${ }^{240} \mathrm{Pu}$ & ICP-MS & $\mu \mathrm{Ci} / \mathrm{mL}$ & $<1.0 \mathrm{E}-02$ & NA \\
\hline${ }^{239,240} \mathrm{Pu}$ & $\alpha$-spectroscopy & $\mu \mathrm{Ci} / \mathrm{mL}$ & $<0.03$ & NA \\
\hline${ }^{241} \mathrm{Pu} /{ }^{241} \mathrm{Am}$ & ICP-MS & $\mu \mathrm{g} / \mathrm{L}$ & $<8.7 \mathrm{E}-03$ & NA \\
\hline${ }^{241} \mathrm{Am}$ & $\gamma$-spectroscopy & $\mu \mathrm{Ci} / \mathrm{mL}$ & $<0.03$ & NA \\
\hline${ }^{242} \mathrm{Cm}$ & $\alpha$-spectroscopy & $\mu \mathrm{Ci} / \mathrm{mL}$ & $<0.15$ & NA \\
\hline${ }^{243,244} \mathrm{Cm}$ & $\alpha$-spectroscopy & $\mu \mathrm{Ci} / \mathrm{mL}$ & $<0.015$ & NA \\
\hline Sum of $\alpha$ & $\alpha$-spectroscopy & $\mu \mathrm{Ci} / \mathrm{mL}$ & $0.00715(0.00020)$ & NA \\
\hline Total $\mathrm{OH}$ & Titration & $\mu \mathrm{g} / \mathrm{mL}$ & $<7.5 \mathrm{E}+04$ & NA \\
\hline Free $\mathrm{OH}$ & Titration & $\mu \mathrm{g} / \mathrm{mL}$ & $<7.5 \mathrm{E}+04$ & NA \\
\hline Density & Gravimetry & $\mathrm{g} / \mathrm{mL}$ & $1.2585(0.0013)$ & $1.253(0.003)$ \\
\hline $\begin{array}{l}\text { Dissolved } \\
\text { Solids }\end{array}$ & Gravimetry & $\begin{array}{c}\mathrm{g} \text { solids/g } \\
\text { supernatant }\end{array}$ & $31.06(0.01)$ & NA \\
\hline
\end{tabular}

Note: Analytes of concern are in italics. * Due to QA failure, reported value is likely to be about $25 \%$ low. See text for details.

AA $=$ atomic absorption spectroscopy

IC = ion chromatography

ICP-AES = inductively coupled plasma-atomic emission spectroscopy

ICP-MS = inductively coupled plasma-mass spectrometry

$\mathrm{LF}=$ laser fluorimetry

LSC = liquid scintillation counting

NA $=$ Not available

$\mathrm{ND}=$ Not detected

$\mathrm{SD}=$ standard deviation

UV-vis = ultraviolet visible

(a) UV-vis measurements for informational purposes only.

(b) Instrument detection limit (but above the minimum reportable quantity).

(c) Single measurement.

(d) Below the minimum reportable quantity, but included because of the relevance of the measurement in determining process performance. 


\section{Acronyms}

\begin{tabular}{|c|c|}
\hline AEA & alpha energy analysis \\
\hline CCD & charged-coupled device \\
\hline CVAA & cold vapor atomic absorption spectroscopy \\
\hline DI & deionized water \\
\hline DOE-RL & U.S. Department of Energy, Richland Operations Office \\
\hline EQL & estimated quantitation limit \\
\hline GEA & gamma energy analysis \\
\hline HLW & high-level waste \\
\hline IC & ion chromatography \\
\hline ICP-AES & inductively coupled plasma-atomic emission spectroscopy \\
\hline ICP-MS & inductively coupled plasma-mass spectrometry \\
\hline GEA & gamma energy analysis \\
\hline LF & laser fluorimetry \\
\hline LSC & liquid scintillation counting \\
\hline MDL & method detection limit \\
\hline MRQ & minimum reportable quantity \\
\hline PES & polyethersulfone \\
\hline QC & quality control \\
\hline RPL & Radiochemical Processing Laboratory \\
\hline RSD & relative standard deviation \\
\hline SAL & Shielded Analytical Laboratory \\
\hline WTP & Waste Treatment Plant \\
\hline SD & standard deviation \\
\hline SST & single-shell tank \\
\hline
\end{tabular}


TC

total carbon

TIC total inorganic carbon

TOC total organic carbon

UV-vis ultraviolet visible 


\section{Acknowledgements}

The authors would like to thank Gregg Lumetta for his technical review of this report, Wayne Cosby for his editorial assistance, Greg Brodaczynski and Lynette Jagoda for their assistance in preparing the quick disconnect connectors and design of the pressure gauge and relief valve assembly, Jackie Deschane for her assistance with the experimental work, and Vaughn Hoopes and Mike Mann for their assistance in the hot-cell operations. 


\section{Contents}

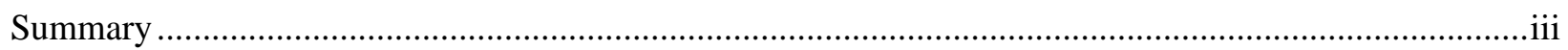

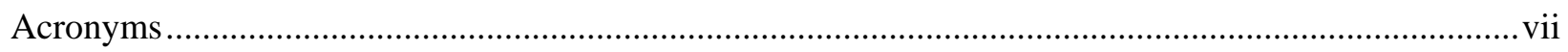

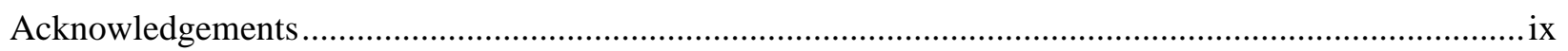

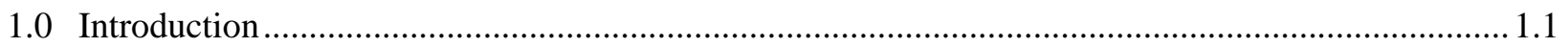

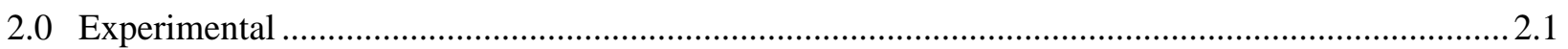

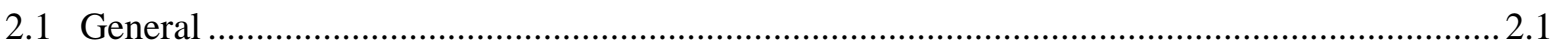

2.2 Preparation of the As-Received Feed Solution .................................................................. 2.1

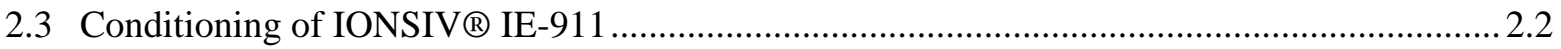

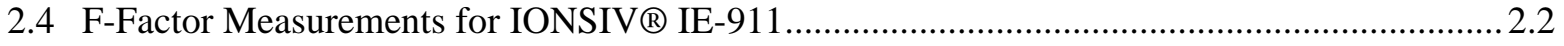

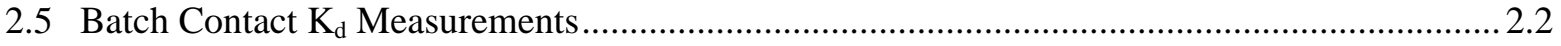

2.6 Preparation and Shakedown Testing of the Ion Exchange Column ........................................ 2.3

2.7 Ion Exchange of the Filtered Feed Solution with IONSIV® IE-911 …..................................... 2.4

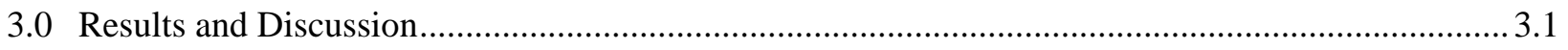

3.1 Generation and Analysis of the Filtered Feed Solution........................................................... 3.1

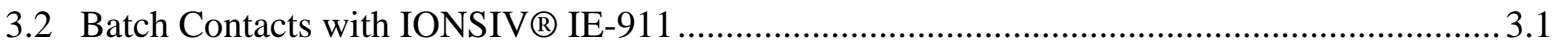

3.3 Column Behavior of IONSIV® IE-911 with the Filtered Feed Solution................................... 3.2

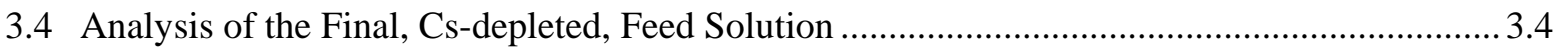

3.4.1 Inductively Coupled Plasma-Atomic Emission Spectroscopy …...................................... 3.4

3.4.2 Determination of Free Hydroxide by Direct Titration.................................................... 3.6

3.4.3 Density and Total Dissolved Solids Measurements ........................................................ 3.6

3.4.4 Mercury Analysis by Cold Vapor Atomic Absorption Spectroscopy ….......................... 3.7

3.4.5 Anion Analysis by Ion Chromatography ................................................................... 3.7

3.4.6 Total Carbon, Total Inorganic Carbon, and Total Organic Carbon by Both Furnace Oxidation and Hot Persulfate Oxidation Methods............................................................ 3.8

3.4.7 Uranium Analysis by Kinetic Phosphoresence................................................................. 3.8

3.4.8 Pertechnetate Analysis by Separation Followed by Beta Liquid Scintillation

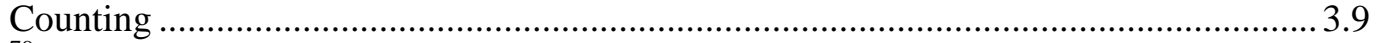

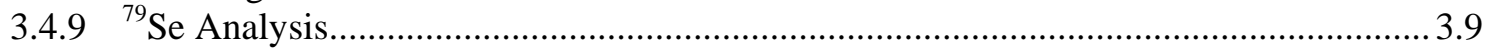

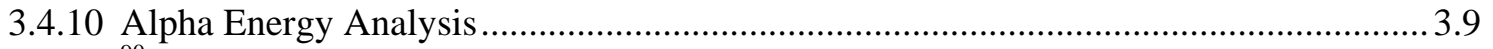

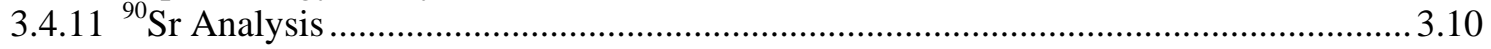

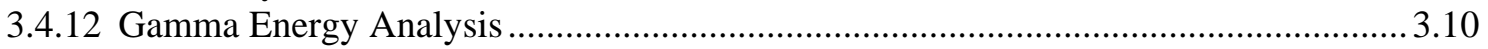


3.4.13 Analysis of ${ }^{99} \mathrm{Tc},{ }^{127} \mathrm{I},{ }^{129} \mathrm{I},{ }^{133} \mathrm{Cs},{ }^{237} \mathrm{~Np},{ }^{239} \mathrm{Pu},{ }^{240} \mathrm{Pu}$, and ${ }^{241} \mathrm{Pu} / \mathrm{Am}$ by Inductively Coupled Plasma-Mass Spectroscopy.

3.4.14 Spectrophotometric Determination of Chromate in the Presence of Nitrate and Nitrite in the Cs-Depleted Feed Solution

4.0 Conclusion

5.0 References

\section{Figures}

2.1. Schematic of Hot Cell IX System

3.1. Spectra of Nitrate, Nitrite, and Chromate at $122.8 \mathrm{mM}, 38.46 \mathrm{mM}$, and $0.164 \mathrm{mM}$

Concentrations, Respectively, in $0.1 \mathrm{M} \mathrm{NaOH}$ Solution (optical path length is $1.055 \mathrm{~cm}$ )

3.2. Spectrum of the Final Composite Solution After a 101-Fold Dilution in $0.1 \mathrm{M} \mathrm{NaOH}$

3.3. Deconvolution of the Cs-Depleted Feed Solution Spectrum into its Separate Components

3.4. Optical Absorbance Spectrum of Undiluted Cs-Depleted Feed Solution

3.5. Spectral Feature Analysis with the Assumption that Chromate and Tetrahydroxochromium(III) only Contribute to the Observed Spectrum 


\section{Tables}

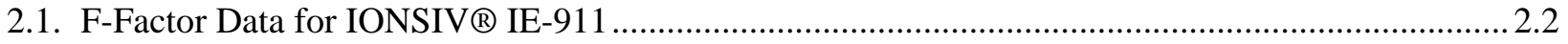

3.1. Filtered Feed Solution Analyses. Major ${ }^{(a)}$ Bulk Components as Determined by ICP-AES,

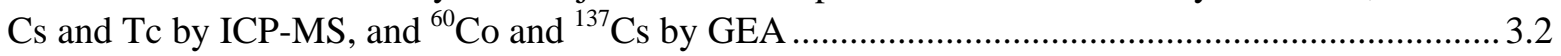

3.2. Summary of Measured ${ }^{137}$ Cs Activity in Column Effluent During Processing ............................... 3.3

3.3. Bulk Components in the Processed Solution as Determined by ICP-AES ..................................... 3.5

3.4. Anion Concentrations in the Processed Solution as Determined by Ion Chromatography ............... 3.7

3.5. TIC, TOC, and TC Analyses by Hot Persulfate and Furnace Oxidation Methods ............................ 3.8

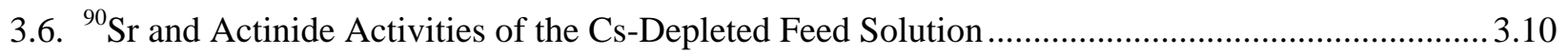

3.7. Radioisotope Concentrations in the Processed Solution as Determined by GEA .......................... 3.10

3.8. ICP-MS Analysis of Cs-Depleted Feed Solution.................................................................... 3.11

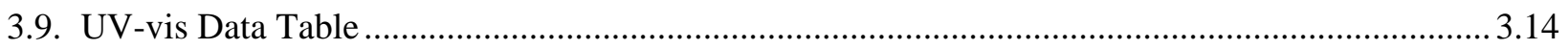




\subsection{Introduction}

Recently, the U.S. Department of Energy's Richland Operations Office (DOE-RL) prepared the Performance Management Plan for the Accelerated Cleanup of the Hanford Site (DOE 2002). This plan proposes an accelerated cleanup for the Hanford Site, with one element of the plan being to complete the processing of the Hanford Site's high-level waste (HLW) by 2028. To accomplish this accelerated schedule, technologies will need to be developed and implemented to supplement the Waste Treatment Plant (WTP) capacity. Several technologies are being considered for supplemental treatment of dissolved salt cake waste. To assess these technologies, laboratory testing is required with actual dissolved saltcake from the Hanford Site’s single-shell tanks (SST).

Gasper et al. (2002) have identified 68 SSTs containing 50,000 gallons or more of saltcake that are considered candidates for treatment by supplemental technologies. For laboratory testing, a saltcake composite should be targeted to represent the wastes contained within these 68 tanks. The saltcake sample used in these tests was designed to meet such a saltcake composition criterion. This saltcake is a composite material, obtained by dissolving archived samples from Hanford SSTs 241-S-101, 241-S-109, 241-S-110, 241-S-111, 241-U-106, and 241-U-109 and adjusted to approximately $5 \mathrm{M}$ Na. The preparation and partial characterization of this dissolved saltcake have been reported. ${ }^{\text {(a) }}$ To reduce the radiation hazard during laboratory testing, the removal of ${ }^{137} \mathrm{Cs}$ (the primary source of penetrating radiation in these solutions) was desired. This report describes the preparation of a ${ }^{137} \mathrm{Cs}$-depleted form of dissolved Hanford tank saltcake by passing the feed solution through a column containing IONSIV® IE911, an inorganic material manufactured by UOP (Des Plaines, IL), which is based on a cesium-selective crystalline silicotitanate. A limited characterization of the initial feed solution and a more extensive characterization of the ${ }^{137}$ Cs-depleted material also are presented in this report. The analytical data in this report updates information presented in an earlier letter report (Rapko et al. 2003). In that report, some preliminary analytical results were reported. In this report, some of that earlier data has been altered but such changes are minor both in impact and number.

(a) WS Callaway. 2002. "Preparation of Ex-Situ Vitrification Test Solution at the 222-S Laboratory." November 6, 2002, letter from WS Callaway (Fluor Hanford) to DW Hamilton (CHG), Correspondence \# FH-0205231. 


\subsection{Experimental}

In this section, the details of the operations needed to process the dissolved saltcake as shipped from the 222-S Laboratory are described.

\subsection{General}

The operations for processing the dissolved saltcake include feed-solution collection, filtration and homogenization, IE-911 preparation for column use, a preliminary test of the IE-911 material's effectiveness at Cs removal, set up and shakedown testing of the IX column, and the actual processing of the filtered feed solution through the IE-911-containing column. Details are also provided concerning the measurement of the ${ }^{137} \mathrm{Cs}$ concentration in the column effluent while processing and measuring selected anions in the combined column effluent by ultraviolet-visible (UV-vis) spectroscopy. The measurements by UV-vis spectroscopy were made for informational purposes only.

With regards to the source and quality of the equipment and chemicals used in these various operations, deionized (DI) water was used to generate the hydroxide solutions by diluting standard solutions using volumetric glassware. All other chemicals used were of reagent grade unless otherwise indicated.

IONSIV ${ }^{\circledR}$ IE-911 (Lot \# 8671-08), an engineered form containing a crystalline silicotitanate as the active Cs-binding material, was obtained from UOP (Des Plaines, IL). A gamma spectrometer with a liquidnitrogen-cooled Ge detector was used to monitor ${ }^{137} \mathrm{Cs}$ activity by measuring the sample's $661 \mathrm{keV}$ emission.

The glass column (5 $\mathrm{cm}$ in diameter and $10 \mathrm{~cm}$ in height), the polyethylene tubing, and miscellaneous adapters used in the ion-exchange procedure were obtained from Spectrum Chromatography (Houston, TX). The variable-rate pump head (Part \# Q1CKC), pump drive, and controller (Part \# QVG50) used in the ion exchange procedure were obtained from Fluid Metering, Inc. (Syosset, NY).

The UV-vis spectroscopic measurements were recorded on a 400 series charged-coupled device (CCD) array UV-vis spectrophotometer (Spectral Instruments Inc., Tucson, AZ). A PLASTIBRAND® cuvette with an extended optical transparency range from 220 to $900 \mathrm{~nm}$ was used for spectrophotometric measurements. The stock solutions of $\mathrm{Na}_{2} \mathrm{CrO}_{4}, \mathrm{NaNO}_{3}$, and $\mathrm{NaNO}_{2}$ needed for calibration experiments were prepared from reagent-grade chemicals dissolved in $0.1 \mathrm{M} \mathrm{NaOH}$. Sodium hydroxide solutions were prepared by appropriate dilutions from a $50 \mathrm{wt} \% \mathrm{NaOH}$ reagent solution in DI water.

\subsection{Preparation of the As-Received Feed Solution}

The feed solution was received from the 222-S Laboratory in 24 bottles. Most of the bottles contained a clear liquid; however, Jars 18, 20, 21, 22, 23, and 24 contained perceptible amounts of gray solids. The contents of each bottle were emptied into a l-L filter device and vacuum filtered through a 0.2-micron polyethersulfone (PES) filter into a 1-L receiving flask. No rinsing of these bottles after decantation was performed. Periodically, the filtered contents in the receiving flask were transferred into a tared, wide mouth, 9-L, polyethylene bottle. The bottles in which the samples were received were weighed both before and after transfer of their contents to the filtration device, and mass balance indicates that $6923 \mathrm{~g}$ of material were so transferred. 
The material filtered without difficulty, even when the contents of the jars contained substantial amounts of solids. By the end of the filtration, the total amount of material collected on the filter was very small, possibly as little as a few grams of solid. No further information was collected with regards to the composition or quantity of these solids. After the filtered material was all combined in the 9-L bottle, a clean paddle was inserted, and the solution was stirred mechanically for over 1 hour. Two $20-\mathrm{mL}$ aliquots of the homogenized liquid were then removed for selected analyses. A 60-mL aliquot was also removed and archived for further analyses if needed. Once filtered, no further precipitates were observed in this material over the remainder of the project (a period of almost 4 months). The density of the homogenized, filtered-feed solution was measured by filling two tared, 5-mL, Type A, volumetric flasks with the filtered feed solution to the 5-mL mark and reweighed. From the weights of each 5-mL sample, an average density for the filtered feed solution of $1.253 \pm 0.003 \mathrm{~g} / \mathrm{mL}$ was calculated.

\subsection{Conditioning of IONSIV ${ }^{\circledR}$ IE-911}

Approximately $150 \mathrm{~mL}$ of the material were suspended in $700 \mathrm{~mL}$ of $1 \mathrm{M} \mathrm{NaOH}$ in a 1-L bottle and agitated using a back-and-forth rocking motion for 2 hours. The supernatant was decanted from the solids, and the supernatant was discarded. Next, the solid was suspended in $700 \mathrm{~mL}$ of DI water, agitated as before for another 2 hours, and the supernatant was again decanted off. This last step with DI water was repeated an additional five times to generate the conditioned material.

\subsection{F-Factor Measurements for IONSIV ${ }^{\circledR}$ IE-911}

Approximately $0.5 \mathrm{~g}$ of unconditioned IONSIV® IE-911 was placed in a $20-\mathrm{mL}$ glass vial. The samples then were heated in an oven for 3 days at $105^{\circ} \mathrm{C}$, allowed to cool, and reweighed. This was done in duplicate. The F-factor, which is the ratio of the dried solids weight to the initial solids weight, was calculated. A summary of the results is provided in Table 2.1.

Table 2.1. F-Factor Data for IONSIV® IE-911

\begin{tabular}{||l|c|c||}
\cline { 2 - 3 } \multicolumn{1}{c|}{} & Data for Sample 1 & Data for Sample 2 \\
\hline \hline Vial tare weight (g) & 16.958 & 17.056 \\
\hline Vial + conditioned sample (g) & 17.445 & 17.528 \\
\hline Weight conditioned sample (g) & 0.487 & 0.470 \\
\hline Vial + dried sample (g) & 17.395 & 17.478 \\
\hline Weight dried sample (g) & 0.437 & 0.422 \\
\hline F-factor & 0.897 & 0.897 \\
\hline
\end{tabular}

\subsection{Batch Contact $\mathbf{K}_{\mathbf{d}}$ Measurements}

In the Shielded Analytical Laboratory's (SAL) hot cells, approximately $0.25 \mathrm{~g}$ of IE-911 was placed in a tared, 20-mL glass vial and reweighed. This was done in duplicate. Then approximately $10 \mathrm{~mL}$ of the filtered, combined, and homogenized feed solution was added, and the system was again weighed. Meanwhile, also in duplicate, a 1-mL aliquot of the initial feed solution was diluted into a known mass (approximately $10 \mathrm{~mL}$ ) of DI water and reweighed. The solution was shaken briefly to mix the contents, and a 1-mL sample of this diluted feed solution was transferred into a tared, 2-dram vial, which was 
reweighed. This aliquot then was removed from the SAL, and its ${ }^{137} \mathrm{Cs}$ activity was measured by monitoring the sample’s 661-keV emission.

Meanwhile, the vials containing the feed solution and IE-911 were shaken at $150 \mathrm{rpm}$ for 68.5 hours at approximately $25^{\circ} \mathrm{C}$. The shaking was stopped, the vial's contents were filtered through a 0.2-micron Nylon ${ }^{\circledR}$ syringe filter, and samples were removed to measure their ${ }^{137} \mathrm{Cs}$ activity as described in the previous paragraph. The batch-distribution coefficients $\left(\mathrm{K}_{\mathrm{d}}\right)$ were then calculated according to the following formula (Brown et al. 1996):

$$
\mathrm{K}_{\mathrm{d}}=\frac{\left(\mathrm{C}_{0}-\mathrm{C}_{\mathrm{i}}\right)}{\mathrm{C}_{\mathrm{i}}} * \frac{\mathrm{V}}{(\mathrm{M} * \mathrm{~F})}
$$

where $\mathrm{K}_{\mathrm{d}}=$ equilibrium batch distribution coefficient (in $\mathrm{mL}$ solution/g solid)

$\mathrm{C}_{0}=$ initial ${ }^{137}$ Cs activity

$\mathrm{C}_{\mathrm{i}}=$ final ${ }^{137}$ Cs activity

$\mathrm{M}=$ mass of IE-911 (in grams) used in the batch-contact experiment

$\mathrm{V}=$ volume of filtered feed solution (in $\mathrm{mL}$ ) used in the batch-contact experiment

$\mathrm{F}=\mathrm{F}$-factor for conditioned IE-911.

\subsection{Preparation and Shakedown Testing of the Ion Exchange Column}

The ion exchange column, pump, tubing, and safety and monitoring device were assembled on a benchtop as illustrated in Figure 2.1. The dead volume in the assembly then was measured as follows: $500 \mathrm{~mL}$ of DI water were pumped through the column. The flowrate through the system was determined by measuring the amount of water passed through the system over a given period of time. With a controller setting of 24.0, a flowrate of $4.1 \mathrm{~mL} / \mathrm{min}(246 \mathrm{~mL} / \mathrm{h})$ of water was calculated. Air was then pumped through the system until no further liquid emerged from the column and for an additional 15 min thereafter. At this time, the stopcock (I) at the bottom of the column was closed, and a pressure-releasing valve (not shown in Figure 2.1) at the top of the column was opened. The controller then was set to 50.0 (flowrate of $8.5 \mathrm{~mL} / \mathrm{min}$ ), the pump was turned on, and passage of water through the system was tracked visually. After 2 minutes 50 seconds of operation, water was observed passing through the tubing and into the column $(\mathrm{G})$. Based on the flowrate of $8.5 \mathrm{~mL} / \mathrm{min}$, this corresponds to the tubing volume of 24 $\mathrm{mL}$. The column itself took 10.0 minutes to fill with water, which corresponds to a dead volume of 85 $\mathrm{mL}$, for a total dead volume to this point of $109 \mathrm{~mL}$. The final dead volume of the tubing between the column and the receiving flask was calculated by filling that section of tubing with water and then transferring the water into a graduated cylinder. In this way, the dead volume of this final section of tubing was estimated at $5 \mathrm{~mL}$ for a total system dead volume of $114 \mathrm{~mL}$.

To eliminate air pockets and voids that might be formed after air-drying of the column during this procedure, the column was unpacked, the IE-911 solids resuspended in DI water, and the column re-packed. The flowrate was rechecked with a controller setting of 50 as described above. A total of 77 $\mathrm{mL}$ of DI water was collected in 9 minutes, which corresponds to the expected flowrate of $8.5 \mathrm{~mL} / \mathrm{min}$.

The performance of the system was examined periodically at different flowrates for several days after the dead-volume measurements but before use with the actual filtered feed solution. A day or two after the 
dead-volume testing described above, a marked increase in the system's back pressure was observed, and a milky white stream exiting the column was noted. The system was disassembled, and the solids were sluiced repeatedly with DI water until the bulk of the readily suspended fine solids was removed. The system then was repacked and flushed extensively with DI water. Fines initially but briefly appeared in the column effluent, but these fine solids soon disappeared, and a clear liquid emerged. Repeated testing of the IX column apparatus was performed over the next several days. No further fines were observed, and no appreciable back pressure was observed with a flowrate up to $600 \mathrm{~mL} / \mathrm{h}$.

\subsection{Ion Exchange of the Filtered Feed Solution with IONSIV® IE-911}

The system was disassembled by its separation into components at the "quick disconnect" connectors (D in Figure 2.1). This breaks up the system into an initial part consisting of tubing and the pump, a middle section consisting of the pressure gauge, pressure relief valve and stand, and a final section consisting of the IX column itself with stand and tubing. These sections were taken into the SAL hot cells and reassembled by attaching the column to a metal stand and re-attaching the tubing at the "quick disconnect" connectors. The feed tube then was placed in a container of $0.25 \mathrm{M} \mathrm{NaOH}$, and the effluent tube was placed into an empty waste container. A $0.25 \mathrm{M} \mathrm{NaOH}$ solution was then pumped through the system at a flowrate of about $600 \mathrm{~mL} / \mathrm{h}$. However, at this flowrate, an increase in the line pressure to about 3.5 psig was observed, and a slow leak at the top of the IX column developed. The flowrate was reduced to a targeted $200 \mathrm{~mL} / \mathrm{h}$, the back pressure dropped to about $2.5 \mathrm{psig}$, and the leak disappeared. A total of about $600 \mathrm{~mL}$ of $0.25 \mathrm{M} \mathrm{NaOH}$ was passed through the column before the feed tube was transferred to the filtered feed solution. The flowrate was set to about $250 \mathrm{~mL} / \mathrm{h}$ for about 30 minutes. The effluent at this time was still being transferred to a waste container. After 30 min of pumping, the flowrate was reduced to about $200 \mathrm{~mL} / \mathrm{h}$, the effluent line was moved to the receipt container (a 9-L polyethylene bottle), and the eluant was collected in the receiving flask. Periodically, the receipt container was weighed, and the effluent line was diverted to an empty, small, glass sample vial to collect an approximately 3-mL aliquot. Monitoring the weight changes in the 9-L bottle as a function of time indicated that a steady flow of the effluent was occurring at a rate of approximately $200 \mathrm{~mL} / \mathrm{h}$. Towards the end of the processing, with about $200 \mathrm{~mL}$ of material left in the feed solution bottle, the feed tube shifted and moved out of the solution. Consequently, air was pumped into the system, and almost all the liquid remaining in the tubing and column was passed into the effluent bottle and replaced by air. The remaining $200 \mathrm{~mL}$ of feed solution was transferred to a small beaker, the feed tube was placed at the bottom of the beaker, and the remaining liquid was pumped through the system. Visual inspection of the system indicates that the column bed was not fully settled during contact with the feed solution for this final $200 \mathrm{~mL}$; some air pockets were observed between the column surface and the column bed. After the contents of the beaker were depleted, the feed tube was transferred back into a reservoir of DI water, and pumping at the flowrate of $200 \mathrm{~mL} / \mathrm{h}$ continued for another one-half hour. The effluent line was then transferred to a waste receptacle, and the system was flushed with approximately $200 \mathrm{~mL}$ of DI water before disassembly. No evidence of solids was observed in any of the column's effluents during any part of this work.

After all of the effluent was collected into the receiving container, the effluent was homogenized by mechanical stirring overnight using a new, clean paddle. Estimates of the samples ${ }^{\text {, }}{ }^{137} \mathrm{Cs}$ activities from weighed, approximately 1-mL, aliquots of the column effluent, as well as for a sample of the homogenized column effluent, were obtained as described above for the IE-911 Cs batch-contact measurements. Duplicate 20-mL aliquots of the homogenized column effluent were obtained and submitted to the RPL Chemical Measurement Center for chemical and radiochemical analysis. 


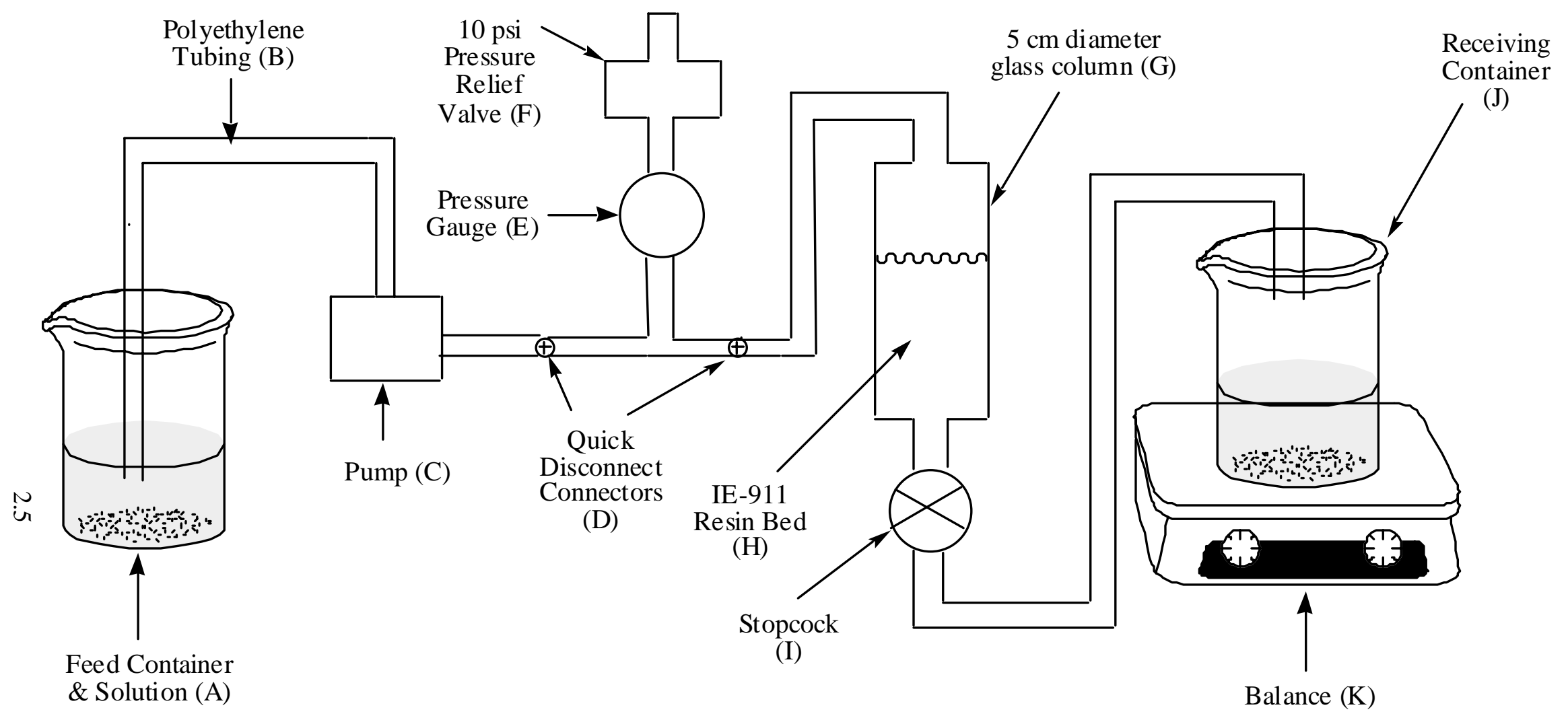

Figure 2.1. Schematic of Hot Cell IX System 


\subsection{Results and Discussion}

\subsection{Generation and Analysis of the Filtered Feed Solution}

The composition of saltcake feed solution shipped from the 222-S Laboratory has been described. ${ }^{\text {(a) }}$ Briefly, the material is a composite of archived samples from SSTs 241-S-101, 241-S-109, 241-S-110, 241-S-111, 241-U-106, and 241-U-109. These materials were suspended in DI water, an aliquot was taken to determine the solution's sodium concentration, additional water was added to adjust the solution sodium concentration to its target of $5 \mathrm{M}$, and the adjusted solution was analyzed to verify the presence of a sodium concentration of approximately $5 \mathrm{M}$. The material was then allowed to settle for several days, and the supernatant was eventually transferred into 250 -mL glass jars for transport to Pacific Northwest National Laboratory.

After receipt of the sample jars at the RPL, the liquid was filtered and homogenized. Aliquots of the initial filtered and homogenized solution were obtained and submitted for analysis for metals content by inductively coupled plasma-atomic emission spectroscopy (ICP-AES), details of which are described below for the Cs-depleted feed solution. The total cesium concentration, however, was determined by inductively coupled plasma-mass spectroscopy (ICP-MS). Selected radionuclides were also measured: ${ }^{60} \mathrm{Co}$ and ${ }^{137} \mathrm{Cs}$ by gamma energy analysis (GEA) and ${ }^{99} \mathrm{Tc}$ by ICP-MS. The results of analyses are shown in Table 3.1. Note that the sodium value agrees well with the approximately $5 \mathrm{M}$ concentration reported by the 222-S Laboratory. In addition, the density of the filtered feed solution was measured. The result from the density measurement, $1.253 \pm 0.003$, agrees well with the specific-gravity measurement, $1.252 \pm$ $0.002 \mathrm{~g} / \mathrm{mL}$, measured at the 222-S Laboratory.

\subsection{Batch Contacts with IONSIV® IE-911}

IONSIV $®$ IE-911 is a material, commercially available from UOP, that is composed of an engineered form of the active ion-exchange material, a crystalline silicotitanate. This ion exchange material has been extensively investigated for the selective removal of cesium from DOE tank supernatants, and the results of this testing have been recently summarized (Hamm et al. 2002). The IE-911 batch used, Lot \# 8671-08, was an early formulation used in a prior test with supernatant from Tank 241-AW-101 (Brown et al. 1996). To verify that acceptable decontamination factors could be obtained with this material batch upon contact with this feed solution, batch contacts were performed in duplicate with IE-911 from Lot \# 8671-08 using the actual filtered feed solution.

The measurements were performed in duplicate and were in excellent agreement with the first Cs $\mathrm{K}_{\mathrm{d}}$ measured as $1170 \mathrm{~mL} / \mathrm{g}$ and the second as $1171 \mathrm{~mL} / \mathrm{g}$ (average $1170 \mathrm{~mL} / \mathrm{g}$ ). These results compare favorably with the batch-contact Cs $\mathrm{K}_{\mathrm{d}}$ reported in Brown et al. (1996) where a value of $710 \mathrm{~mL} / \mathrm{g}$ was reported. One possible reason for the greater $\mathrm{K}_{\mathrm{d}}$ observed here is that at $5 \mathrm{M} \mathrm{Na}$, 241-AW-101 contains about five times the potassium concentration $(0.48 \mathrm{M})$ as the solution tested here. It is known that potassium competes with cesium for binding to IE-911, so the higher potassium concentrations present in

(a) WS Callaway. 2002. "Preparation of Ex-Situ Vitrification Test Solution at the 222-S Laboratory." November 6, 2002, letter from WS Callaway (Fluor Hanford) to DW Hamilton (CHG), Correspondence \# FH-0205231. 
241-AW-101 would, all other variables being equal, be expected to depress an observed Cs $\mathrm{K}_{\mathrm{d}}$. In addition, the initial [Na]/[Cs] ratio of this feed solution, 260,000, is much greater than that of 241-AW101 (78,000). With an initial cesium concentration of 2E-05 M, it has been shown (Hamm et al. 2002) that IONSIV ${ }^{\circledR}$ IE-911 is in a linear region of the cesium isotherm. This implies that, all other things being equal, the $\mathrm{K}_{\mathrm{d}}$ for contact with this feed solution should be greater, as observed, than with contact with 241-AW-101. The magnitude of the observed $K_{d}$ indicates that this material, despite several years of storage, should still be able to effectively remove cesium from the filtered feed solution.

Table 3.1. Filtered Feed Solution Analyses. Major ${ }^{(a)}$ Bulk Components as Determined by ICP-AES, Cs and Tc by ICP-MS, and ${ }^{60} \mathrm{Co}$ and ${ }^{137} \mathrm{Cs}$ by GEA

\begin{tabular}{|c|c|c|c|c|}
\hline $\begin{array}{c}\text { Est. Quant. Limit. } \\
\text { (EQL), } \mu \mathrm{g} / \mathrm{mL}\end{array}$ & Analyte & $\begin{array}{c}\text { Ave Conc., } \\
\mu \mathrm{g} / \mathrm{mL}\end{array}$ & $\begin{array}{l}\text { Standard Deviation } \\
\text { of Conc., } \mu \mathrm{g} / \mathrm{mL}\end{array}$ & Ave Conc., $\mathrm{M}$ \\
\hline 0.446 & $\mathrm{Al}$ & 5700 & 54 & 2.1E-01 \\
\hline 0.081 & $\mathrm{Ca}$ & 88 & 6 & 2.2E-03 \\
\hline 0.017 & $\mathrm{Cr}$ & 990 & 7 & $1.9 \mathrm{E}-02$ \\
\hline 10.406 & $\mathrm{~K}$ & 410 & 22 & $1.0 \mathrm{E}-02$ \\
\hline 0.750 & $\mathrm{Na}$ & 120000 & 500 & $5.1 \mathrm{E}+00$ \\
\hline 0.234 & $\mathrm{P}$ & 1800 & 17 & $5.8 \mathrm{E}-02$ \\
\hline 0.305 & $\mathrm{Si}$ & 110 & 14 & $3.9 \mathrm{E}-03$ \\
\hline 0.0037 & Cs & 2.52 & 0.02 & 1.90E-05 \\
\hline NA & ${ }^{99} \mathrm{Tc}^{(\mathrm{b})}$ & $2.37^{(\mathrm{c})}$ & 0.02 & 2.37E-05 \\
\hline NA & ${ }^{60} \mathrm{Co}$ & $0.00562^{(\mathrm{d})}$ & $0.00079^{(\mathrm{c})}$ & -- \\
\hline NA & ${ }^{137} \mathrm{Cs}$ & $46.6^{(\mathrm{d})}$ & $0.35^{(\mathrm{c})}$ & -- \\
\hline \multicolumn{5}{|c|}{$\begin{array}{l}\text { NA = Not reported. } \\
\text { (a) Defined as being present in }>50 \mu \mathrm{g} / \mathrm{mL} \text {. ICP-AES } \\
\text { (b) QC failure suggests this value may be low. See text } \\
\text { (c) This corresponds to an activity of } 0.0403 \mu \mathrm{Ci} / \mathrm{mL} \text {. } \\
\text { (d) In units of } \mu \mathrm{Ci} / \mathrm{mL} \text {. }\end{array}$} \\
\hline
\end{tabular}

\subsection{Column Behavior of IONSIV® IE-911 with the Filtered Feed Solution}

The relatively wide, 5-cm-diameter column used in this work was chosen for two reasons. First, the large volume of ion exchange material (about $150 \mathrm{~mL}$ ) meant that $<40$ bed volumes of solution would be needed to process the approximately $5.5 \mathrm{~L}$ of feed solution. In addition, the wide column means that a low superficial velocity (the distance the surface moves during a given period of time) can be used to process the solution and still complete the processing in a timely manner. Lower superficial velocities generally translate into more effective component removal. The superficial velocity used in the processing of this solution is low compared to previous studies; the $200 \mathrm{~mL} / \mathrm{h}$ flowrate translates into a superficial velocity of only $0.17 \mathrm{~cm} / \mathrm{min}$. During previous studies with superficial velocities of 0.27 to $1.06 \mathrm{~cm} / \mathrm{min}, 100$ to more than 500 column volumes of solution were processed before any increase in eluate cesium concentration was observed (Hamm et al. 2002). However, such comparisons are inexact because differing component concentrations and batches of IE-911 were used. Still, with the low number of bed volumes needed to process this solution as well as the low superficial velocity used, the system was designed intentionally to maximize cesium removal. 
The processing was qualitatively monitored periodically by examining aliquots of column effluent for ${ }^{137} \mathrm{Cs}$ activity, and the results were generally as expected. Table 3.2 summarizes the observed decontamination factors.

In general, except for the values at $90 \mathrm{~mL}$ of processed solution, $5272 \mathrm{~mL}$ of processed solution, and the initial and final composite samples, no visual signal at $661 \mathrm{keV}$ could be observed after counting for 100 minutes; for these measurements, no ratios of the measured ${ }^{137} \mathrm{Cs}$ concentration divided by the initial ${ }^{137} \mathrm{Cs}$ concentration $\left(\mathrm{C} / \mathrm{C}_{0}\right)$ can be reported. In essence then, except for the initial and final processing samples, no detectable ${ }^{137} \mathrm{Cs}$ appears in the column effluent. The reasons for the presence of cesium in the initial and final samples may be similar. Initially, despite the several bed volumes of alkaline solution passed through the column before the feed solution was introduced, the column bed might not have been fully settled, and some channeling of the feed solution through the column may have occurred. Between the 4.5- and 5.3-L sampling events, the feed tube was displaced from the solution, and air was passed through the system. Consistent with visual observation, the bed might not have been fully settled when the final amounts of feed solution again were passed through the system, resulting again in a small amount of channeling. However, despite any cesium removal inefficiencies associated with this possible channeling, the processing of the filtered feed solution through the IE-911 column resulted in a composite with good ${ }^{137} \mathrm{Cs}$ decontamination, with an overall C/ $\mathrm{C}_{0}$ of 3.15E-05 or, alternatively, with an overall decontamination factor of greater than 30,000.

Table 3.2. Summary of Measured ${ }^{137}$ Cs Activity in Column Effluent During Processing

\begin{tabular}{|c|c|c|c|c|}
\hline $\begin{array}{l}\text { mL Feed Solution } \\
\text { Processed }\end{array}$ & $\begin{array}{l}\text { Est. Cumulative } \\
\text { Bed Volumes } \\
\text { Processed }^{(a)}\end{array}$ & $\begin{array}{c}\text { Estimated } \\
\text { Superficial } \\
\text { Velocity }(\mathrm{cm} / \mathrm{min})\end{array}$ & $\begin{array}{l}\text { Measured }{ }^{137} \mathrm{Cs} \\
\text { Activity }(\mathrm{cpm} / \mathrm{g} \\
\text { eluate) }\end{array}$ & $\mathrm{C} / \mathrm{C}_{0}$ \\
\hline 0 & 0 & NA & 70162 & $1.00 \mathrm{E}+00$ \\
\hline 90 & 0.6 & $1.53 \mathrm{E}-01$ & 3 & $4.25 \mathrm{E}-05$ \\
\hline 338 & 2.3 & $1.80 \mathrm{E}-01$ & 2 & $2.72 \mathrm{E}-05$ \\
\hline 896 & 6.0 & $1.58 \mathrm{E}-01$ & 1 & 7.65E-06 \\
\hline 1499 & 10.0 & $1.70 \mathrm{E}-01$ & ND & -- \\
\hline 2113 & 14.1 & $1.74 \mathrm{E}-01$ & ND & -- \\
\hline 2715 & 18.1 & $1.70 \mathrm{E}-01$ & ND & -- \\
\hline 3316 & 22.1 & $1.70 \mathrm{E}-01$ & ND & -- \\
\hline 3898 & 26.0 & $1.64 \mathrm{E}-01$ & ND & -- \\
\hline 4527 & 30.2 & $1.78 \mathrm{E}-01$ & 1 & $1.06 \mathrm{E}-05$ \\
\hline 5272 & 35.1 & $1.46 \mathrm{E}-01$ & 6 & 8.90E-05 \\
\hline Final composite & NA & NA & 2 & $3.15 \mathrm{E}-05$ \\
\hline \multicolumn{5}{|c|}{$\begin{array}{l}\text { NA = Not applicable } \\
\text { ND = No signal detected. } \\
\text { (a) = neglects prior analytical samples taken. }\end{array}$} \\
\hline
\end{tabular}




\subsection{Analysis of the Final, Cs-depleted, Feed Solution}

Extensive analytical data on the combined column effluent is provided in this section. Requested analyses include numerous metals by ICP-AES; the uranium concentration by kinetic phosphorescence; the solution density and total dissolved solids by gravimetry; hydroxide by acid titration, total organic carbon (TOC) and total inorganic carbon (TIC) by both furnace oxidation and silver-catalyzed persulfate oxidation methods; concentrations of gamma-emitting isotopes by gamma energy analysis (GEA); concentrations of alpha emitting isotopes and total alpha activity by alpha energy analysis (AEA); pertechnetate, ${ }^{79} \mathrm{Se}$ and ${ }^{90} \mathrm{Sr}$ by selective separation followed by liquid scintillation counting; mercury by cold vapor atomic absorption spectroscopy (CVAA); selected anions by ion chromatography (IC), and the concentrations of various radioisotopes by ICP-MS. The method used for each of these analyses will be briefly described, the results summarized, and any issues impacting the evaluation of the results noted. In some cases, the analytical method provides information on additional species outside of the requested analytes of interest. In these instances, the analytes of interest are specifically identified. Finally, UV-visible spectroscopy is applied for analysis of the concentrations of major anions such as chromate, nitrate and nitrite. This study is for informational purposes only, with no specific quality requirements applied.

\subsubsection{Inductively Coupled Plasma-Atomic Emission Spectroscopy}

The samples were prepared by an acid digest following procedure PNL-ALO-128 using a nominal sample of $1.0 \mathrm{~mL}$ and diluting to a final volume of approximately $25 \mathrm{~mL}$. The samples were analyzed according to PNL-ALO-211. The detected analytes at or above the estimated quantitation limit (EQL, equivalent to 10 times the method detection limit [MDL]) were reported with an uncertainty of $\pm 15 \%(2-\sigma)$. As the MDL was approached, uncertainty increased to $100 \%$.

Because of the limited number (only $\mathrm{Na}$ ) of analytes requested for analysis in the initial feed solution together with the high Na concentration in the sample, measurements were made with solutions diluted an additional five times from the preparation described above. For the final feed solution, measurements were made, because of the larger number of analytes of interest, both on samples prepared as described above and those diluted an additional five times. Because of the high dissolved salt levels in the undiluted sample, the efficiency of the instrument can be reduced, which results in a slight reduction (3 to $5 \%$ ) in the indicated analyte concentrations. Results with fivefold diluted material are presented as applicable; results for undiluted samples are given for those cases where the data are subject to less certainty, i.e., where the fivefold dilution data are $<\mathrm{EQL}$ or $<\mathrm{MDL}$, and the undiluted sample data are $>$ EQL or MDL, respectively.

The only element for which the minimum reportable quantity (MRQ) was not met, i.e., the MDL was less than one-third the MRQ, was for cerium, which was only detected in one of the four sample measurements (duplicate submitted aliquots each performed in duplicate). All other quality control tests were acceptable with the following exceptions: the relative percent differences in the duplicates exceeded the acceptance criteria ( $\pm 15 \%$ for all elements but $\mathrm{Na}$, which is $\pm 3.5 \%$ ) in selected measurements of Ca, $\mathrm{K}$, and Na. For one sample at five times dilution and its duplicate, calcium was slightly out of tolerance at $16 \%$; between the two samples themselves, potassium was slightly out of tolerance at $16 \%$ and sodium at $5 \%$. 
Table 3.3 summarizes the metals content for the processed solution. The average value and its associated standard deviation are provided along with the molarity of the solution in that component, the molarity of the initial solution in the same component, and the percent of the component remaining in the solution following processing for Cs removal.

Table 3.3 indicates that the solution composition, with the exception of Cs removal, was little altered by contact with IONSIV® IE-911. Significant depletion in the concentration of $\mathrm{Ca}, \mathrm{Fe}$, and $\mathrm{Pb}$ was observed. Some removal of Ca, Fe, and K by IE-911 from Hanford Site tank supernatants has been reported previously (Hamm et al. 2002; Brown et al. 1996).

Table 3.3. Bulk Components in the Processed Solution as Determined by ICP-AES

\begin{tabular}{|c|c|c|c|c|c|c|}
\hline (Analyte) & $\begin{array}{c}\text { Estimated } \\
\text { Quantitation } \\
\text { Limit } \\
(\mu \mathrm{g} / \mathrm{mL})\end{array}$ & $\begin{array}{c}\text { Average } \\
\text { Conc. } \\
(\mu \mathrm{g} / \mathrm{mL})\end{array}$ & $\begin{array}{c}\text { Standard } \\
\text { Deviation of } \\
\text { Conc. }(\mu \mathrm{g} / \mathrm{mL})\end{array}$ & $\begin{array}{c}\text { Process } \\
\text { Solution } \\
\text { Molarity, } \\
\text { M }\end{array}$ & $\begin{array}{c}\text { Initial } \\
\text { Feed, M }\end{array}$ & $\begin{array}{c}\% \\
\text { Agreement } \\
\text { (Final/Initial) }\end{array}$ \\
\hline$A l$ & 0.446 & 5600 & 78 & 2.07E-01 & 2.11E-01 & 99 \\
\hline$B a$ & 0.010 & $0.1^{(\mathrm{a})}$ & NA & 3.64E-07 & -- & NA \\
\hline $\mathrm{Ca}$ & 0.450 & 57 & 9.5 & $1.42 \mathrm{E}-03$ & 2.19E-03 & 65 \\
\hline$C d$ & 0.038 & 3.4 & 0.1 & 3.00E-05 & 3.33E-05 & 90 \\
\hline $\mathrm{Ce}$ & 0.400 & 1.1 & NA & 7.85E-06 & -- & NA \\
\hline $\mathrm{Cr}$ & 0.060 & 965 & 8.3 & $1.86 \mathrm{E}-02$ & $1.90 \mathrm{E}-02$ & 98 \\
\hline $\mathrm{Fe}$ & 0.100 & 1.6 & 0.2 & 2.87E-05 & 4.70E-05 & 61 \\
\hline$K$ & 10.000 & 353 & 28 & 9.02E-03 & $1.02 \mathrm{E}-02$ & 87 \\
\hline$L a$ & 0.130 & $0.57^{(\mathrm{a})}$ & NA & 4.10E-06 & -- & NA \\
\hline $\mathrm{Na}$ & 0.870 & 117000 & 2500 & $5.10 \mathrm{E}+00$ & $5.14 \mathrm{E}+00$ & 99 \\
\hline $\mathrm{Ni}$ & 0.130 & 37 & 0.2 & 6.35E-04 & $6.60 \mathrm{E}-04$ & 96 \\
\hline$P$ & 0.236 & 1650 & 48 & 5.32E-02 & $5.80 \mathrm{E}-02$ & 92 \\
\hline$P b$ & 0.264 & $4.6^{(\mathrm{a})}$ & NA & 2.22E-05 & 5.55E-05 & 40 \\
\hline$U$ & 4.971 & $22^{(a)}$ & NA & 9.24E-05 & -- & NA \\
\hline $\mathrm{B}$ & 0.031 & 22 & 0.5 & 1.99E-03 & $2.07 \mathrm{E}-03$ & 96 \\
\hline Mo & 0.057 & 17 & 0.3 & $1.81 \mathrm{E}-04$ & 1.89E-04 & 96 \\
\hline $\mathrm{Pd}$ & 1.250 & 19 & 5 & $1.74 \mathrm{E}-04$ & 1.62E-04 & 105 \\
\hline $\mathrm{Si}$ & 0.298 & 111 & 12 & 3.93E-03 & 3.94E-03 & 100 \\
\hline $\mathrm{W}$ & 0.130 & 32 & 1.0 & $1.76 \mathrm{E}-04$ & 1.93E-04 & 91 \\
\hline \multicolumn{7}{|c|}{$\begin{array}{l}\text { Note: Analytes of interest shown in italics. Non-analy } \\
\text { two significant figures. } \\
--=\text { Below detection limit. } \\
\text { NA = Not available (insufficient data for calculation). } \\
\text { (a) Not detected in all samples. }\end{array}$} \\
\hline
\end{tabular}




\subsubsection{Determination of Free Hydroxide by Direct Titration}

The amount of free hydroxide was measured by direct titration of duplicate submitted samples, with each submitted sample performed in duplicate, with a standard $\mathrm{HCl}$ solution according to procedure PNL-ALO-228. Good reproducibility ( $\pm 5 \%$ or better relative standard deviation [RSD]) was observed. The free hydroxide concentration was derived from the first inflection point in the titration curve and yielded a value of $0.51 \pm 0.1 \mathrm{M}$, well below the MRQ of 4.4 M. No quality control (QC) issues are associated with this measurement. The total hydroxide equivalents (approximately $2 \mathrm{M}$ ) are also below the MRQ.

Some pertinent information, together with the assignments provided in the analytical report, is as follows. The initial observed $\mathrm{pH}$ of the supernatant was about 12 . The first equivalence point (about $0.5 \mathrm{M}$ ) was observed at $\mathrm{pH} 11$, the second equivalence point (about $0.9 \mathrm{M}$ ) was observed at $\mathrm{pH} 8$, and the third equivalence point (about $0.6 \mathrm{M}$ ) was observed at $\mathrm{pH}$ 4.6. The standard assignment is that the first equivalence point reflects the concentration of free hydroxide and that the second and third equivalents reflect the acid neutralization of carbonate and bicarbonate, respectively. Because of the complexity of this sample, the analysis may be somewhat more complicated in this instance. The $\mathrm{pH}$ of the sample observed initially is low for a solution $0.5 \mathrm{M}$ in free hydroxide. However, this could be caused by poor electrode response of the $\mathrm{pH}$ electrode in highly alkaline solution coupled with the high ionic strength of the solution. The equivalents consumed for carbonate and bicarbonate for a solution of this high initial $\mathrm{pH}$ should be approximately equivalent since the carbonate should be initially all in its fully deprotonated form $\left(\mathrm{CO}_{3}{ }^{2-}\right)$. However, contrary to this expectation, the data indicate a higher effective base concentration at the second equivalence points than the third. This could be explained by the presence of aluminum, which exists in solution primarily as tetrahydroxyaluminate, $\left[\mathrm{Al}(\mathrm{OH})_{4}\right]^{-}$. From the ICP-AES data, the $\mathrm{Al}$ concentration is about $0.2 \mathrm{M}$. Deprotonation of the one hydroxide equivalent associated with aluminum, together with the assumption that the third equivalence point is due to protonation of bicarbonate, would give reasonable agreement with the experimental data.

Both theoretical and analytical data support this interpretation. For instance, the best TOC (i.e., carbonate) value (see discussion below) is $6400 \mu \mathrm{g} \mathrm{C} / \mathrm{mL}$ or $0.53 \mathrm{M}$, consistent with the interpretation of the third, ca. 0.6 M, equivalence point as bicarbonate. Using $0.53 \mathrm{M}$ carbonate, a balance of the sum of the major cations and anions should indicate whether a large or small free hydroxide concentration is present. The high, 5.2 M, concentration of sodium dominates the total cation concentration. The major anion concentrations are $0.53 \mathrm{M}$ carbonate (from TIC), $2.44 \mathrm{M}$ nitrate (by IC), $0.41 \mathrm{M}$ nitrite (by IC), $0.21 \mathrm{M}$ tetrahydroxyaluminate (by ICP-AES) and 0.093 M sulfate (by IC). The difference of 5.2 - (2 • 0.53) $2.44-0.41-0.21-(2 \bullet 0.093)=$ a calculated contribution for sodium hydroxide of about $0.9 \mathrm{M}$, an acceptable agreement for such an analysis. In addition, a simulation of the potentiometric titration curve using the above concentrations for free hydroxide, tetrahydroxyaluminate and carbonate, fully supports the above interpretation. In short, solution concentration for the Cs-depleted feed solution of about 0.5 to $0.6 \mathrm{M}$ in carbonate, $0.2 \mathrm{M}$ in aluminum, and $0.5 \mathrm{M}$ free hydroxide best interpret the experimental data.

\subsubsection{Density and Total Dissolved Solids Measurements}

Gravimetric measurements were used to calculate both the weigh percent dissolved solids and the density. The density was determined according to procedure PNL-ALO-501. This procedure involves the measurement of the weight change of a 1-mL aliquot added to a Class A 1-mL volumetric flask. The 
density measurement of each of the duplicate submitted samples was done in triplicate with excellent reproducibility (RSD $<0.1 \%$ ), yielding a measured density of $1.2585 \pm 0.0012 \mathrm{~g} / \mathrm{mL}$. No QC issues are associated with this measurement.

The weigh percent dissolved solids was determined according to procedure PNL-ALO-504. This procedure involves drying a known weight of material to a constant weight at approximately $105^{\circ} \mathrm{C}$ and measuring the weight change. A weight percent dissolved solids value of $31.06 \pm 0.1 \%$ was obtained. No QC issues are associated with this measurement.

\subsubsection{Mercury Analysis by Cold Vapor Atomic Absorption Spectroscopy}

The mercury concentration of the Cs-depleted feed solution was measured according to procedures RPG-CMC-131 and RPG-CMC-201, which describe an aqueous digestion of a sample aliquot followed by analysis by CVAA. The measured concentration was less than the estimated quantitation limit of 5.0 $\mu \mathrm{g} / \mathrm{L}$ and below the MRQ of $1.5 \mu \mathrm{g} / \mathrm{mL}$. In addition, the measured value of $1.7 \pm 0.1 \mu \mathrm{g} / \mathrm{L}$ is very close to the process blank concentration of $1.6 \mu \mathrm{g} / \mathrm{L}$. The only QC issue to arise for this measurement was associated with the recovery (72\%) in the measured low-level standard $(0.05 \mu \mathrm{g} / \mathrm{L})$, which is slightly outside of the QC acceptance criterion of $100 \pm 25 \%$.

\subsubsection{Anion Analysis by Ion Chromatography}

IC was used to identify and quantify inorganic anions in the Cs-depleted feed solution according to procedure PNL-ALO-212. The results of this analysis are summarized in Table 3.4. The samples required significant dilution (1,000 to 10,000 -fold), both to reach the calibration range of the instrument and to not overload the IC column with material. The fluoride peak exhibited significant broadening, which is indicative of the presence of other, co-eluting anions. Therefore, the fluoride value must be considered as an upper-bounding value. No other QC issues were associated with the analytes of interest.

Table 3.4. Anion Concentrations in the Processed Solution as Determined by Ion Chromatography

\begin{tabular}{|c|c|c|c||}
\hline Component & Average Molarity $(\mathbf{M})$ & $\begin{array}{c}\text { Average Concentration } \\
(\mu \mathbf{g} / \mathbf{m L})\end{array}$ & $\begin{array}{c}\text { Concentration Standard } \\
\text { Deviation }(\mu \mathbf{g} / \mathbf{m L})\end{array}$ \\
\hline $\mathrm{F}$ & $1.84 \mathrm{E}-02$ & $3.49 \mathrm{E}+02$ & $5 \mathrm{E}+00$ \\
\hline $\mathrm{Cl}$ & $4.15 \mathrm{E}-02$ & $1.47 \mathrm{E}+03$ & $3 \mathrm{E}+01$ \\
\hline $\mathrm{NO}_{2}{ }^{-}$ & $4.13 \mathrm{E}-01$ & $1.90 \mathrm{E}+04$ & $2 \mathrm{E}+02$ \\
\hline $\mathrm{Br}$ & $1.63 \mathrm{E}-03$ & $1.30 \mathrm{E}+02$ & $0.00 \mathrm{E}+00$ \\
\hline $\mathrm{NO}_{3}{ }^{-}$ & $2.44 \mathrm{E}+00$ & $1.51 \mathrm{E}+05$ & $1 \mathrm{E}+03$ \\
\hline $\mathrm{PO}_{4}{ }^{3-}$ & $5.12 \mathrm{E}-02$ & $4.86 \mathrm{E}+03$ & $1.3 \mathrm{E}+02$ \\
\hline $\mathrm{SO}_{4}{ }^{2-}$ & $9.32 \mathrm{E}-02$ & $8.95 \mathrm{E}+03$ & $2 \mathrm{E}+01$ \\
\hline $\mathrm{C}_{2} \mathrm{O}_{4}{ }^{2-}$ & $1.42 \mathrm{E}-02$ & $1.25 \mathrm{E}+03$ & $5.7 \mathrm{E}+02$ \\
\hline Note: Analytes of interest in italics.
\end{tabular}




\subsubsection{Total Carbon, Total Inorganic Carbon, and Total Organic Carbon by Both Furnace Oxidation and Hot Persulfate Oxidation Methods}

Both a hot persulfate oxidation method and a furnace oxidation method were used to analyze total carbon (TC), TIC, and TOC. The results from both methods are shown in Table 3.5.

The hot persulfate oxidation was performed according to procedure PNL-ALO-381 and involves an acid decomposition to remove inorganic carbon (carbonate) as carbon dioxide, followed by a silver(I) catalyzed reaction with potassium persulfate at 92 to $95^{\circ} \mathrm{C}$ to remove organic carbon as carbon dioxide. Both of these reactions are followed with a coulometric detector. The TC is determined by adding the TIC and TOC values. There were no QC issues associated with this analysis, which is generally considered to give values that are precise to $\pm 15 \%$ or better.

The furnace oxidation was performed according to procedure PNL-ALO-380 and involves combustion of the sample at $650^{\circ} \mathrm{C}$ for 10 minutes to determine TOC and combustion at $1000^{\circ} \mathrm{C}$ to determine TC. The combustion is followed with a coulometric detector. The TIC value is determined by the TC value minus the TOC value. There were no QC issues associated with this analysis, which also is generally considered to give values that are precise to $\pm 15 \%$ or better.

Although the agreement between the two methods in the TC results is reasonable, there are substantial discrepancies in the relative weightings of TOC and TIC. As noted in the analysis report, this poor agreement is not unusual, and the recommended approach is to take the TC value as measured by the furnace oxidation method (which is a direct measurement rather than a summation as in the persulfate oxidation method) and the TIC value as measured by the persulfate oxidation method and then to calculate the TOC value by the difference. This has been done in the "recommended values" column in Table 3.5.

Table 3.5. TIC, TOC, and TC Analyses by Hot Persulfate and Furnace Oxidation Methods

\begin{tabular}{|l|c|c|c|}
\hline \multicolumn{1}{|c|}{ Component } & $\begin{array}{c}\text { Average Value (SD) by } \\
\text { Furnace Oxidation } \\
(\mu \mathbf{g} / \mathbf{m L})\end{array}$ & $\begin{array}{c}\text { Average Value (SD) by } \\
\text { Persulfate Oxidation } \\
(\boldsymbol{\mu g} / \mathbf{m L})\end{array}$ & $\begin{array}{c}\text { Recommended Values } \\
(\boldsymbol{\mu g} / \mathbf{m L})\end{array}$ \\
\hline Total Inorganic Carbon & $4420(20)$ & $6400(20)$ & 6400 \\
\hline Total Organic Carbon & $5370(20)$ & $2800(60)$ & 3380 \\
\hline Total Carbon & $9780(40)$ & $9190(90)$ & 9780 \\
\hline SD = Standard Deviation & \multicolumn{3}{|l|}{} \\
\hline
\end{tabular}

\subsubsection{Uranium Analysis by Kinetic Phosphoresence}

An initial uranium separation was performed according to an abbreviated version of procedure RPG-CMC-4017. This involves digestion with concentrated $\mathrm{HCl}$ and loading of the uranium onto an anion exchange column, washing with a $\mathrm{HCl}$ solution, and then elution with dilute nitric acid. The uranium concentration was then analyzed by a method based on kinetic phosphorescence according to procedure RPG-CMC-4014 to yield an average value ( \pm one standard deviation) of 1.08E-02 $\pm 0.04 \mathrm{E}-02$ $\mu \mathrm{g} U / \mathrm{mL}$. No QC issues were identified for this measurement. 


\subsubsection{Pertechnetate Analysis by Separation Followed by Beta Liquid Scintillation Counting}

A pertechnetate analysis was performed according to a procedure PNL-ALO-432 for the pertechnetate separation and procedure RPG-CMC-474 for its quantitation by liquid scintillation counting of the beta activity. The pertechnetate separation was slightly modified by omitting the oxidation of any low valent technetium to pertechnetate and proceeding directly with passing the sample through a cation exchanger followed by pertechnetate extraction from the column effluent with a tetraphenylarsonium salt in methyl isobutyl ketone. Removal of the ketone followed by liquid scintillation counting of the beta activity of the residue gave an average pertechnetate activity for the Cs-depleted feed solution of 4.22E-02 \pm $0.29 \mathrm{E}-02 \mu \mathrm{Ci} / \mathrm{mL}$. No QC issues were associated with this re-analysis.

In an earlier version of this report, a value of $3.39 \mathrm{E}-02 \pm 0.25 \mathrm{E}-02 \mu \mathrm{Ci} / \mathrm{mL}$ was reported. However, it was later determined that the actual pertechnetate concentrations of the standards were about $25 \%$ greater than the values used to generate the calibration curves and, from the calibration curves, the pertechnetate concentrations of the initial and Cs-depleted materials. Having the samples more concentrated than the "book" value leads to a lower than true determination of the pertechnetate concentration. The reason for the standards being more concentrated than expected was attributed to evaporation. Because the calibration curves were generated some time before the measurements that revealed that the book value and measured values were about $25 \%$ apart, it was uncertain as to what the actual technetium concentration of the standards was at the time the analyses were performed. For this reason, the pertechnetate and ${ }^{99}$ Tc concentrations of the Cs-depleted materials were remeasured; the remeasured values are reported above. Consistent with an about $25 \%$ error in the book to actual Tc concentrations, which would lead to the original reported value being as little as $75 \%$ of true, the original pertechnetate concentration was only $20 \%$ lower than the remeasured pertechnetate concentration.

\subsection{9 $\quad{ }^{79}$ Se Analysis}

This analysis was performed by first separating out the Se according to procedure PNL-ALO-440 followed by measuring the Se beta activity by liquid scintillation counting according to procedure PNL-ALO-474. The selenium is isolated by first adding some selenium carrier to the solution followed by acidification with $\mathrm{HBr}$ to achieve a neutral selenium compound. Other materials are removed from the matrix by passing the solution through a mixed cation-anion exchange column. The effluent is transferred to a still, and the Se is distilled off as a chloride. The beta activity of the distillate is then determined by liquid scintillation counting. This analysis gave an average ${ }^{79}$ Se activity for the Cs-depleted feed solution of $1.94 \pm 0.43 \mathrm{E}-05 \mu \mathrm{Ci} / \mathrm{mL}$, which is below the minimum reportable quantity of $9.0 \mathrm{E}-05 \mu \mathrm{Ci} / \mathrm{mL}$. The RPD of $32 \%$ was about twice the acceptable amount of $\pm 15 \%$. The reason for this is unknown but is possibly related to severe quenching observed with one sample during liquid scintillation counting.

\subsubsection{Alpha Energy Analysis}

The activities of alpha-emitting isotopes in the Cs-depleted feed solution were measured by alpha energy analysis according to procedure PNL-ALO-422, following a separation performed according to procedure PNL-ALO-4001. This initial separation involves co-precipitation of the actinide with $\mathrm{NdF}_{3}$, following introduction of titanium trichloride to reduce uranium, neptunium, and plutonium to their lower, +3 , oxidation states. The precipitate is then mounted on a membrane filter, and the material's alpha emissions 
are measured by alpha spectroscopy. The average activity of the alpha emitters is summarized in Table 3.6. No QC issues are associated with these measurements.

\subsubsection{1 ${ }^{90}$ Sr Analysis}

The ${ }^{90} \mathrm{Sr}$ activity in the Cs-depleted feed solution was measured by counting on a beta proportional counter according to PNL-ALO-408, following an initial separation of the ${ }^{90} \mathrm{Sr}$ according to procedure PNL-ALO-476. The initial separation of the ${ }^{90} \mathrm{Sr}$ is performed by passing the material through a column that selectively removes the ${ }^{90} \mathrm{Sr}$ by extraction chromatography with a crown ether acting as the agent that selectively complexes strontium. The ${ }^{90} \mathrm{Sr}$ is then removed from the column with a water elution, and the beta activity of the eluate is measured as previously described. The average ${ }^{90} \mathrm{Sr}$ activity is summarized in Table 3.6. No QC issues are associated with this measurement.

Table 3.6. ${ }^{90} \mathrm{Sr}$ and Actinide Activities of the Cs-Depleted Feed Solution

\begin{tabular}{|c|c|c|}
\hline Isotope & Average Activity $(\mu \mathrm{Ci} / \mathrm{mL})$ & Standard Deviation $(\mu \mathrm{Ci} / \mathrm{mL})$ \\
\hline${ }^{90} \mathrm{Sr}$ & $6.84 \mathrm{E}-03$ & $2.1 \mathrm{E}-04$ \\
\hline${ }^{239} \mathrm{Pu}$ and ${ }^{240} \mathrm{Pu}$ & $3.14 \mathrm{E}-04$ & $2.6 \mathrm{E}-05$ \\
\hline${ }^{238} \mathrm{Pu}$ and ${ }^{241} \mathrm{Am}^{(\mathrm{a})}$ & $6.50 \mathrm{E}-03$ & $1.7 \mathrm{E}-04$ \\
\hline${ }^{243} \mathrm{Cm}$ and ${ }^{244} \mathrm{Cm}$ & 3.04E-04 & $2.6 \mathrm{E}-05$ \\
\hline${ }^{242} \mathrm{Cm}$ & $3.26 \mathrm{E}-05$ & $3.1 \mathrm{E}-06$ \\
\hline Total alpha sum & 7.15E-03 & $2.0 \mathrm{E}-04$ \\
\hline \multicolumn{3}{|c|}{$\begin{array}{l}\text { Note: Analytes of interest are in italics. } \\
\text { (a) The }{ }^{241} \mathrm{Am} \text { activity determined by GEA analysis indicates that the majority of this activity is }{ }^{241} \mathrm{Am} \text {, } \\
\text { with }{ }^{238} \mathrm{Pu} \text { being only a minor contributor, at best. }\end{array}$} \\
\hline
\end{tabular}

\subsubsection{Gamma Energy Analysis}

The identity and activity of gamma-emitting isotopes in the Cs-depleted feed solution were evaluated by gamma spectroscopy performed according to PNL-ALO-450. The results are summarized in Table 3.7. No QC issues are associated with this measurement.

Table 3.7. Radioisotope Concentrations in the Processed Solution as Determined by GEA

\begin{tabular}{||c|c|c||}
\hline \hline Isotope & Average Activity $(\boldsymbol{\mu C i} / \mathbf{m L})$ & Activity Standard Deviation $(\boldsymbol{\mu C i} / \mathbf{m L})$ \\
\hline${ }^{60} \mathrm{Co}$ & $6.81 \mathrm{E}-03$ & $2.5 \mathrm{E}-04$ \\
\hline${ }^{152} \mathrm{Eu}$ & $1.71 \mathrm{E}-04$ & $6 \mathrm{E}-06$ \\
\hline${ }^{126} \mathrm{Sn} /{ }^{126} \mathrm{Sb}$ & $2.69 \mathrm{E}-04$ & $1.0 \mathrm{E}-05$ \\
\hline${ }^{137} \mathrm{Cs}$ & $1.21 \mathrm{E}-03$ & $2.0 \mathrm{E}-04$ \\
\hline${ }^{154} \mathrm{Eu}$ & $8.89 \mathrm{E}-03$ & $3.9 \mathrm{E}-04$ \\
\hline${ }^{155} \mathrm{Eu}$ & $4.66 \mathrm{E}-03$ & $2.9 \mathrm{E}-04$ \\
\hline${ }^{241} \mathrm{Am}$ & $6.45 \mathrm{E}-03$ & $5.4 \mathrm{E}-04$ \\
\hline \multicolumn{2}{|l}{ Note: Analytes of interest are in italics. } \\
\hline
\end{tabular}


The identified radioisotopes are those commonly associated with tank supernatants, ${ }^{60} \mathrm{Co},{ }^{152,154,155} \mathrm{Eu}$, ${ }^{126} \mathrm{Sn}\left({ }^{126} \mathrm{Sb}\right),{ }^{241} \mathrm{Am}$, and, of course, ${ }^{137} \mathrm{Cs}$. In general, most of the gamma activity in tank supernatants comes from ${ }^{137} \mathrm{Cs}$. Consistent with the decontamination factors observed by monitoring with the $\mathrm{Ge}$ detector, processing of the feed solution through a IE-911 column has markedly reduced the ${ }^{137}$ Cs activity in the processed solution. Indeed, it is no longer even the major source of activity in solution, with more (based on activity) ${ }^{154,155} \mathrm{Eu},{ }^{241} \mathrm{Am}$, and ${ }^{60} \mathrm{Co}$ now present in the processed solution.

\subsubsection{Analysis of ${ }^{99} \mathrm{Tc},{ }^{127} \mathrm{I},{ }^{129} \mathrm{I},{ }^{133} \mathrm{Cs},{ }^{237} \mathrm{~Np},{ }^{239} \mathrm{Pu},{ }^{240} \mathrm{Pu}$, and ${ }^{241} \mathrm{Pu} / \mathrm{Am}$ by Inductively Coupled Plasma-Mass Spectroscopy}

ICP-MS was used to measure the concentrations of ${ }^{99} \mathrm{Tc},{ }^{127} \mathrm{I},{ }^{129} \mathrm{I},{ }^{133} \mathrm{Cs},{ }^{237} \mathrm{~Np},{ }^{239} \mathrm{Pu},{ }^{240} \mathrm{Pu}$, and ${ }^{241} \mathrm{Pu} / \mathrm{Am}$ in the Cs-depleted feed solution. The results of these measurements are shown in Table 3.8. There were no QC issues associated with these measurements with the exception of cesium isotopic and ${ }^{129}$ I analyses. No cesium isotopes were detected; however, the MDL of $13 \mu \mathrm{g} / \mathrm{L}$ for ${ }^{133} \mathrm{Cs}$ was substantially greater than the requested MRQ of 7E-04 $\mu \mathrm{g} / \mathrm{L}$ for ${ }^{133} \mathrm{Cs}$, and the MDL of $0.013 \mathrm{mg} / \mathrm{L}$ for ${ }^{137} \mathrm{Cs}$ was greater than the requested MRQ of $1.5 \mu \mathrm{Ci} / \mathrm{mL}$ or $0.0094 \mathrm{mg} / \mathrm{L}$ for ${ }^{137} \mathrm{Cs}$. The ${ }^{129} \mathrm{I}$ analysis has an over-recovery of $160 \%$ for the matrix spike, although the blank spike recovery was excellent (98\%). In addition, the MRQ of $0.08 \mathrm{mg} / \mathrm{L}$ could not be met; however, since the actual samples had concentrations well above the minimum detection limit, the inability to achieve the MRQ is of no practical consequence.

Table 3.8. ICP-MS Analysis of Cs-Depleted Feed Solution

\begin{tabular}{|c|c|c|c|}
\hline Analyte & Ave. Concentration (mg/L) & Standard Deviation & Ave. Concentration $(\mu \mathrm{Ci} / \mathrm{mL})$ \\
\hline${ }^{99} \mathrm{Tc}$ & $3.19 \mathrm{E}+00$ & $0.096 \mathrm{E}+00$ & $5.41 \mathrm{E}-02$ \\
\hline${ }^{127} I$ & 8.99E-01 & 2.21E-02 & $7.08 \mathrm{E}-06^{(\mathrm{a})}$ \\
\hline${ }^{129} I$ & 3.31E-01 & $1.34 \mathrm{E}-02$ & 5.85E-05 \\
\hline${ }^{133} \mathrm{Cs}$ & $<0.013$ & NA & -- \\
\hline${ }^{137} \mathrm{Cs}$ & $<0.0094$ & NA & -- \\
\hline${ }^{237} \mathrm{~Np}$ & 2.73E-03 & 0.09E-03 & 1.92E-06 \\
\hline${ }^{239} \mathrm{Pu}$ & 3.53E-03 & $0.11 \mathrm{E}-03$ & 2.19E-04 \\
\hline${ }^{240} \mathrm{Pu}$ & $2.44 \mathrm{E}-04$ & $0.06 \mathrm{E}-04$ & 5.53E-05 \\
\hline${ }^{241} \mathrm{Pu}$ and ${ }^{241} \mathrm{Am}$ & $1.73 \mathrm{E}-03$ & $0.06 \mathrm{E}-03$ & -- \\
\hline
\end{tabular}

As noted in the above section describing the pertechnetate analysis, the analysis results for ${ }^{99} \mathrm{Tc}$ reported in the initial report were in error due to a discrepancy of about $25 \%$ between the book value and the true value for the Tc standards. These standards were used for the ${ }^{99}$ Tc ICP-MS analysis as well as the pertechnetate analysis. In the earlier report, the average measured concentration was $2.43 \mathrm{mg} / \mathrm{L}$. As described in the pertechnetate section, the expectation of having the standards about $25 \%$ more concentrated than the concentrations assigned in the instrument calibration would be to have the earlier reported value only $75 \%$ of true. Consistent with that analysis, the ratio of the original ${ }^{99} \mathrm{Tc}$ analysis by ICP-MS and a more recent analysis reveals that the original reported result is indeed $24 \%$ lower than the new result. The similar changes in the pertechnetate and ${ }^{99} \mathrm{Tc}$ analyses also indicate that no detectable 
change in the pertechnetate ${ }^{99} \mathrm{Tc}$ ratio occurred during the approximately 6 months between the first and more recent analysis. This re-analysis also does not change the observation that about $20 \%$ of the Tc present in this SST dissolved saltcake composite is not in the form of pertechnetate. Finally, it is of interest to note that analysis of the ICP-MS spectrum indicates that the m/e 99 peak is solely due to technetium-99 and that the pattern in this area of the spectrum is solely due to fission product contributions, i.e., there is no naturally occurring material interference that would require a correction to the $\mathrm{m} / \mathrm{e} 99$ signal.

\subsubsection{Spectrophotometric Determination of Chromate in the Presence of Nitrate and Nitrite in the Cs-Depleted Feed Solution}

It is of interest to understand the chemical speciation of chromium in the Cs-depleted feed solution; in particular to determine whether chromium is present in the +6 oxidation state (as chromate, $\mathrm{CrO}_{4}{ }^{2-}$ ) or in the +3 oxidation state $\left(\right.$ as $\left.\left[\mathrm{Cr}(\mathrm{OH})_{4}^{-}\right]\right)$. UV-vis spectroscopy provides a convenient method to evaluate this speciation because of the strong differences in their visible spectra. However, other species present in tank waste, in particular nitrate and nitrite, can overlap with the chromate spectrum, thus complicating its interpretation.

The analysis of such a mixture of components is a common analytical problem in spectrophotometry. If the spectra of pure components are available, the spectrum of a mixture can be analyzed to determine the concentrations of the individual components. If the mixture contains $N$ components, then absorbance measurements at $N$ suitable wavelengths are necessary to solve the set of $N$ linear equations in $N$ unknowns. The application of this approach to the Cs-depleted feed solution is given below.

To analyze a mixture of chromate, nitrate, and nitrite, it is sufficient to measure the optical density of the composite at three different wavelengths. The spectra of the individual ions and of a mixture are shown in Figure 3.1 and Figure 3.2. 


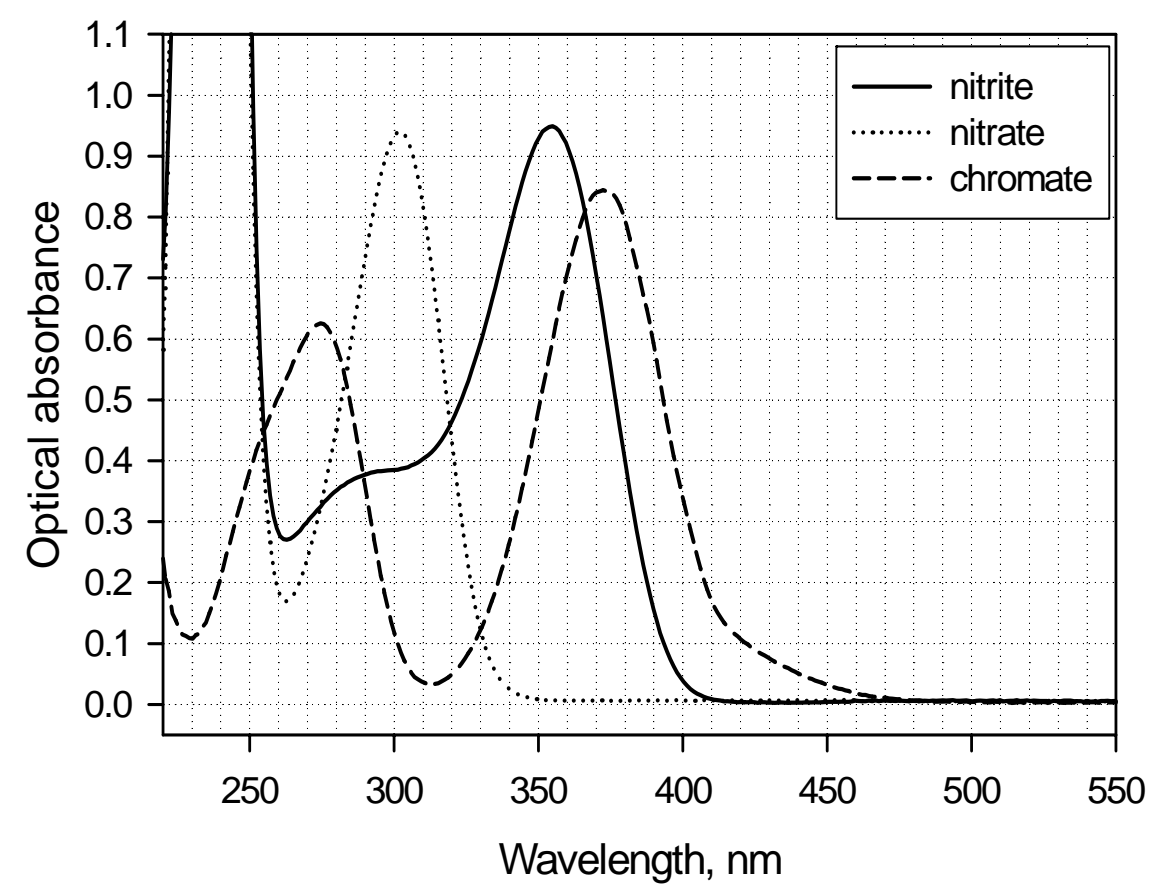

Figure 3.1. Spectra of Nitrate, Nitrite, and Chromate at $122.8 \mathrm{mM}, 38.46 \mathrm{mM}$, and $0.164 \mathrm{mM}$ Concentrations, Respectively, in $0.1 \mathrm{M} \mathrm{NaOH}$ Solution (optical path length is $1.055 \mathrm{~cm}$ )

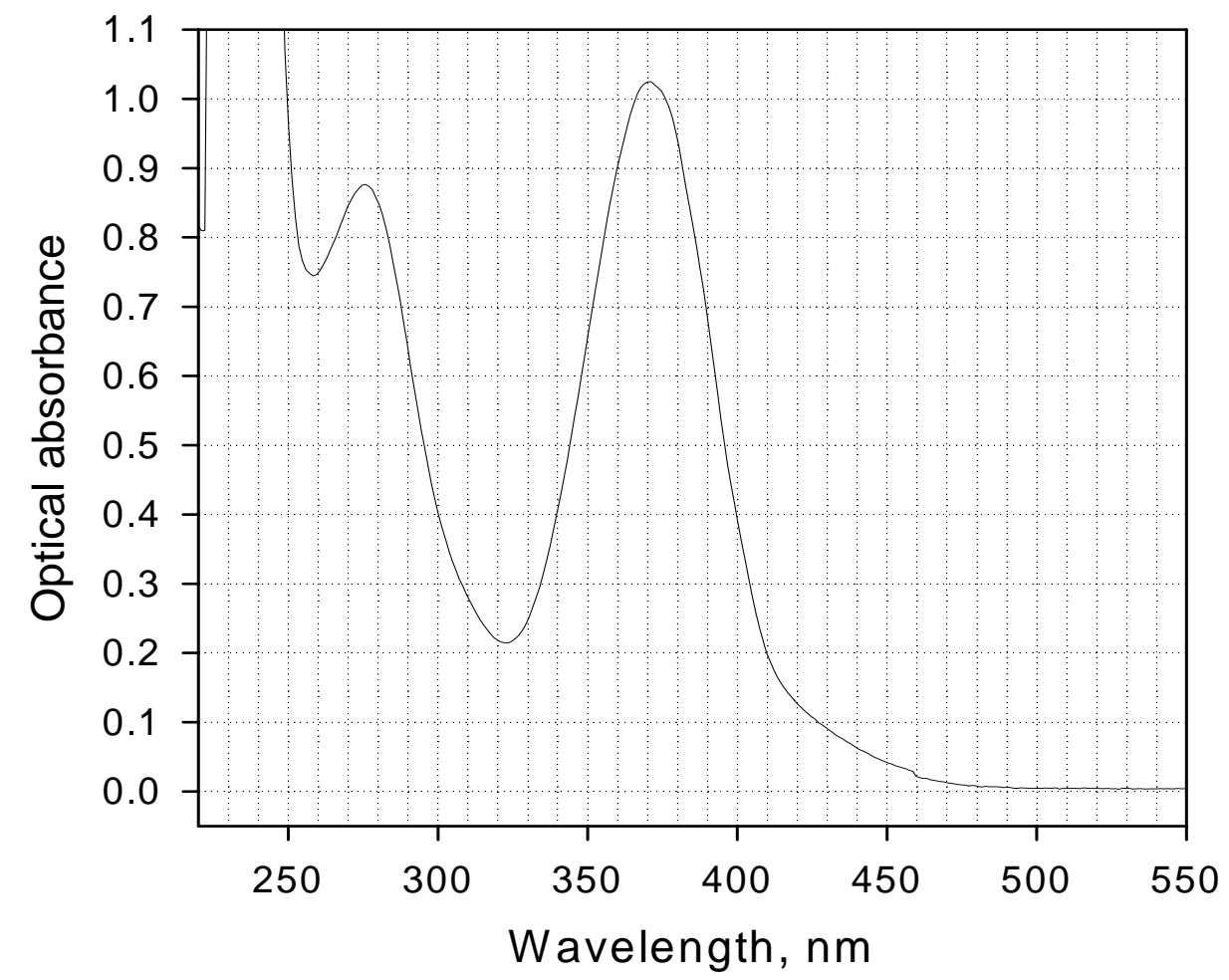

Figure 3.2. Spectrum of the Final Composite Solution After a 101-Fold Dilution in 0.1 M NaOH 
The most suitable wavelengths for analysis are 302, 354, and $372 \mathrm{~nm}$ as determined from an examination of the most intense peaks' maxima positions.

The Beer's law for this three-component mixture can be written as shown below:

$$
\begin{aligned}
& \varepsilon_{302}^{\text {chromate }} \times[\text { chromate }]+\varepsilon_{302}^{\text {nitrate }} \times[\text { nitrate }]+\varepsilon_{302}^{\text {nitrite }} \times[\text { nitrite }]=A_{302} / l \\
& \varepsilon_{354}^{\text {chromate }} \times[\text { chromate }]+\varepsilon_{354}^{\text {nitrate }} \times[\text { nitrate }]+\varepsilon_{354}^{\text {nitrite }} \times[\text { nitrite }]=A_{354} / l \\
& \varepsilon_{372}^{\text {chromate }} \times[\text { chromate }]+\varepsilon_{372}^{\text {nitrate }} \times[\text { nitrate }]+\varepsilon_{372}^{\text {nitrite }} \times[\text { nitrite }]=A_{372} / l
\end{aligned}
$$

where $\boldsymbol{\varepsilon}$ and $\boldsymbol{A}$ are molar absorptivity and optical absorbance of the solution at the selected wavelength, values in square brackets refer to the species concentration in the solution, and $\boldsymbol{l}$ is the optical pathlength of a spectrophotometric cell (a plastic cell with $l=1.055 \mathrm{~cm}$ was used in spectral measurements described in this section).

The molar absorptivities of the three species at the specified wavelengths are given in Table 3.9.

A graphical deconvolution of the spectra is summarized in Figure 3.3. From this analysis, the chromate concentration in the diluted solution was determined to be $0.184 \mathrm{mM}$. Without taking into account the interfering absorbances form nitrate and nitrite, the concentration of chromate calculated from its absorbance peak intensity at $372 \mathrm{~nm}$ in Figure $3.2(\mathrm{~A}=1.02)$ would be overestimated by $8.5 \%$. Similarly, the concentrations of nitrate and nitrite are found to be $27.2 \mathrm{mM}$ and $4.7 \mathrm{mM}$, respectively. After correcting for sample dilution, the chromate concentration in the Cs-depleted feed solution is measured as $0.0186 \mathrm{M}$, the nitrate concentration as $2.74 \mathrm{M}$, and the nitrite concentration as $0.475 \mathrm{M}$. The latter two concentrations are in good agreement with the IC results, which report a nitrate concentration of $2.44 \mathrm{M}$

\begin{tabular}{|c|c|c|c|c|}
\hline & \multicolumn{2}{|c|}{ Molar Absorptivity x l, $\mathrm{M}^{-1}(\mathrm{l}=1.055 \mathrm{~cm})$} & & \\
\hline$\lambda(\mathbf{n m})$ & $\mathrm{CrO}_{4}{ }^{2-}$ & $\mathrm{NO}_{3}^{-}$ & $\mathrm{NO}_{2}^{-}$ & A, Cs-Depleted Feed Solution \\
\hline 302.49 & 583 & 7.7 & 10.06 & 0.3642 \\
\hline 353.75 & 3465 & 0.01 & 24.5 & 0.7542 \\
\hline 372.38 & 5116 & 0.001 & 16.55 & 1.0204 \\
\hline
\end{tabular}
and a nitrite concentration of $0.413 \mathrm{M}$.

Table 3.9. UV-vis Data Table

Comparison of the found chromate concentration with the value of the total chromium concentration determined by ICP-AES $(0.0186 \mathrm{M})$ indicates that there is no statistically significant concentration difference between the two values. However, additional analysis of the visible spectrum can directly address the relative oxidation states of chromium in the solution by analyzing the 372-nm region where the absorbance for chromate is at a maximum, and $590 \mathrm{~nm}$, where a major absorbance for $\mathrm{Cr}(\mathrm{OH})_{4}{ }^{-}$is centered. 


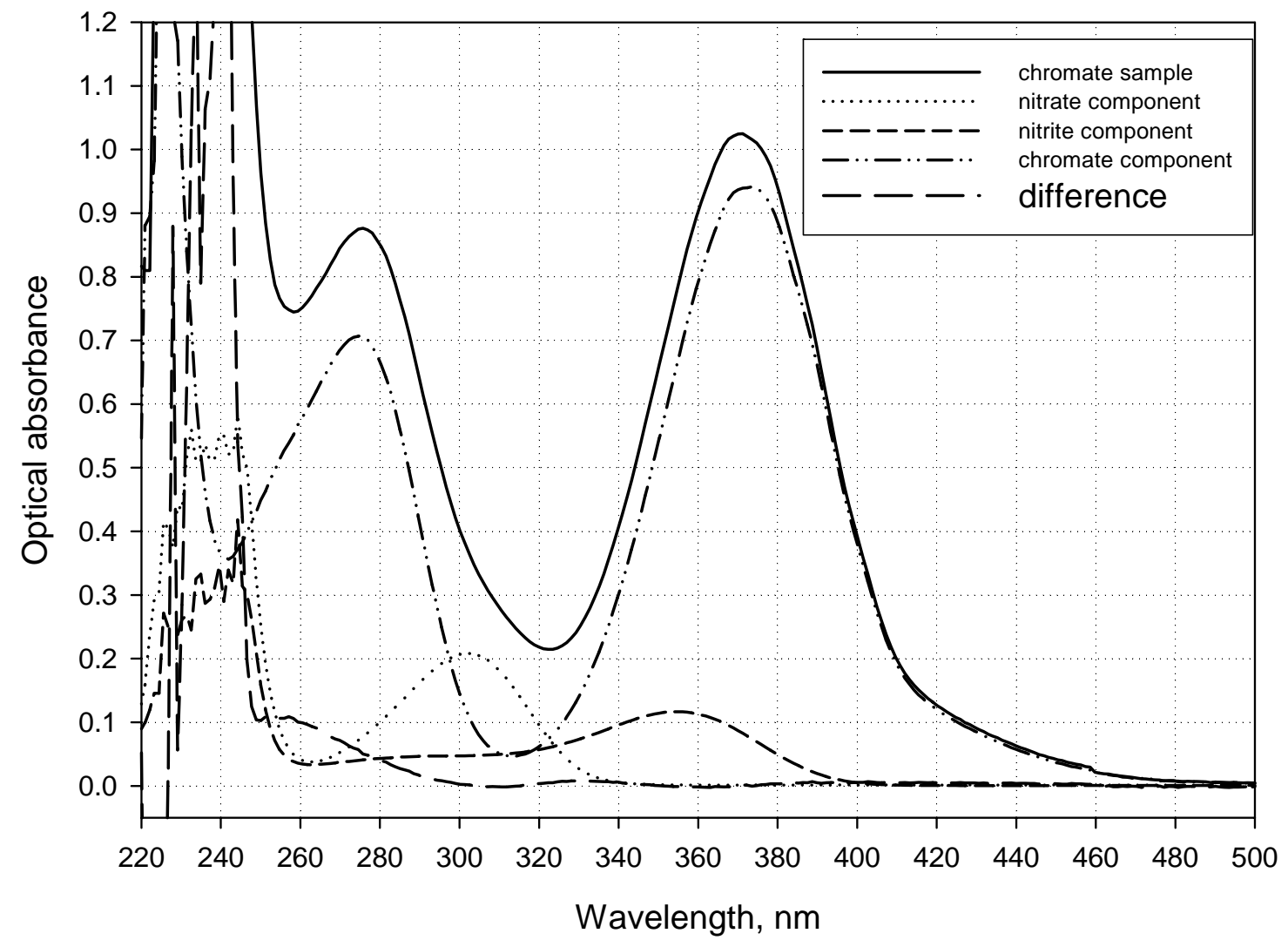

Figure 3.3. Deconvolution of the Cs-Depleted Feed Solution Spectrum into its Separate Components

Figure 3.4 provides the visible spectrum for the Cs-depleted feed solution in the region from approximately $425 \mathrm{~nm}$ to $950 \mathrm{~nm}$. An expanded scale is shown as an insert. A weak but distinct spectral feature is evident with an observed maximum at $570 \mathrm{~nm}$. This wavelength position is $20 \mathrm{~nm}$ off compared with the $590 \mathrm{~nm}$ of $\mathrm{Cr}(\mathrm{OH})_{4}{ }^{-}$species, but this difference might be attributable to the effect of tailing from the main peak of chromate centered at $372 \mathrm{~nm}$. The absorbance from the latter is so huge with a chromate concentration of $0.0186 \mathrm{M}$ that its presence can be seen even some $200 \mathrm{~nm}$ away from the maximum. Qualitatively, superposition of the weak and broad 590-nm peak onto a steep tail from the 372-nm peak may significantly affect the spectral shape of the former by shifting the apparent maximum to a shorter wavelength. 


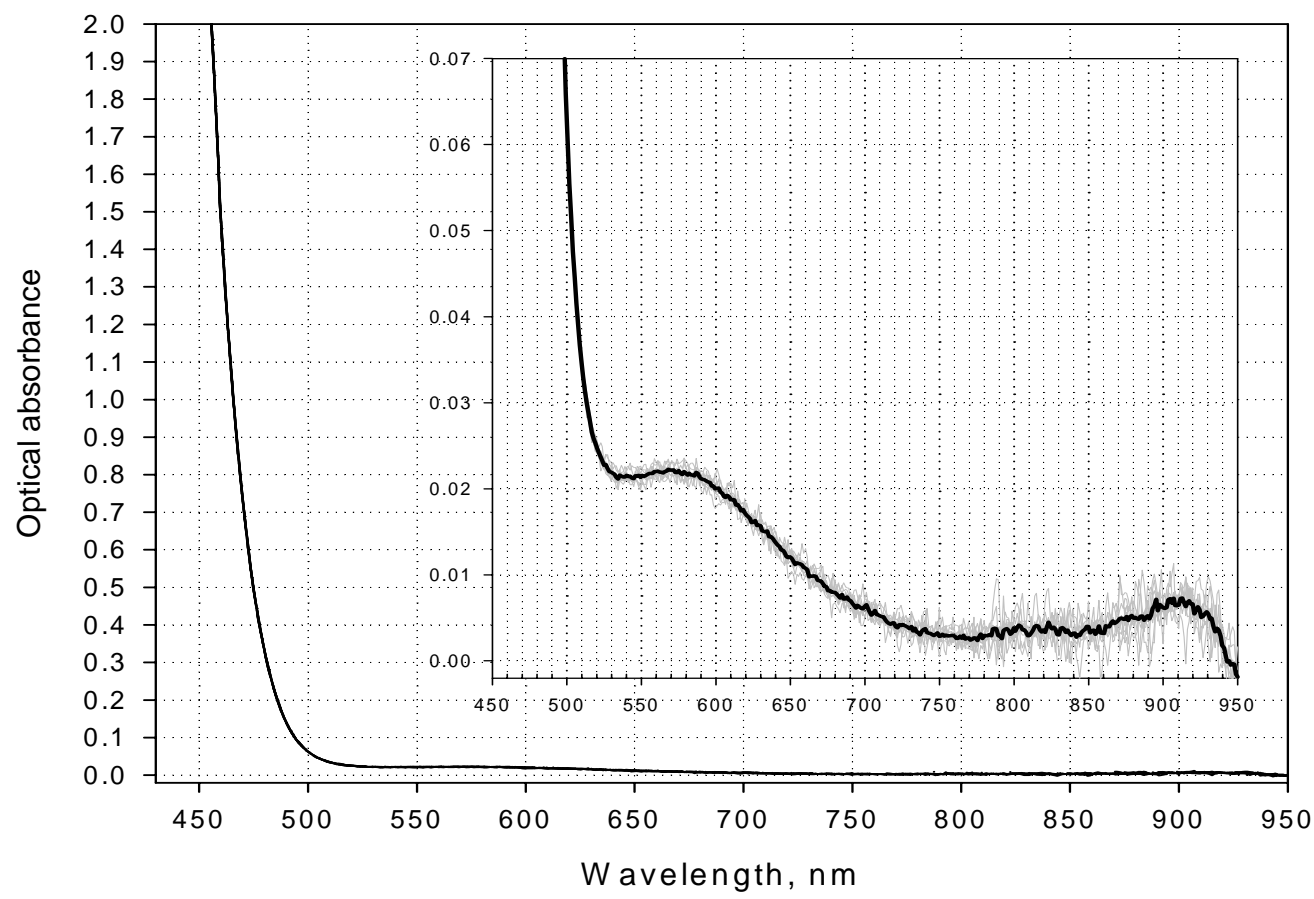

Figure 3.4. Optical Absorbance Spectrum of Undiluted Cs-Depleted Feed Solution. Grey traces represent nine single scans. The bold line is the averaged spectrum.

To see whether this assumption may explain the observed 20-nm difference in the spectrum of the proposed contribution from tetrahydroxychromate, a $0.0186 \mathrm{M}$ solution of chromate in $0.1 \mathrm{M} \mathrm{NaOH}$ was prepared; its spectrum is shown in Figure 3.5. It is apparent that the chromate absorbance levels off to the horizontal baseline at zero absorbance starting from $540 \mathrm{~nm}$. It further indicates that all residual absorbance at $570 \mathrm{~nm}(\mathrm{~A}=0.022)$ should come from the suspected anionic tetrahydroxocomplex of $\mathrm{Cr}(\mathrm{III})$. Such a level of optical absorbance would formally correspond to a $0.022 / 25.4=8.6610^{-4} \mathrm{M}$ concentration of $\mathrm{Cr}(\mathrm{III})$, which would indicate that as much as $4.5 \%$ of the total chromium concentration is present as the $\mathrm{Cr}$ (III) species. However, an attempt to recreate the experimentally observed spectrum at these concentrations of $\mathrm{Cr}(\mathrm{VI})$ and $\mathrm{Cr}(\mathrm{III})$ does not give an adequate correspondence between the real and the "synthetic" spectrum. If $\operatorname{Cr}(\mathrm{III})$ were the only species contributing to the overall absorbance in the 540 - to $700-\mathrm{nm}$ range and if its concentration were of $0.866 \mathrm{mM}$, the valley at $530 \mathrm{~nm}$ should be seen much more clearly (red trace in Figure 3.5) versus the local maximum at 585 to $590 \mathrm{~nm}$. To put it in a more quantitative language, $A_{530}$ should be not higher that 0.012 , as opposed to actual observation of $\mathrm{A}_{530}=0.022$. 


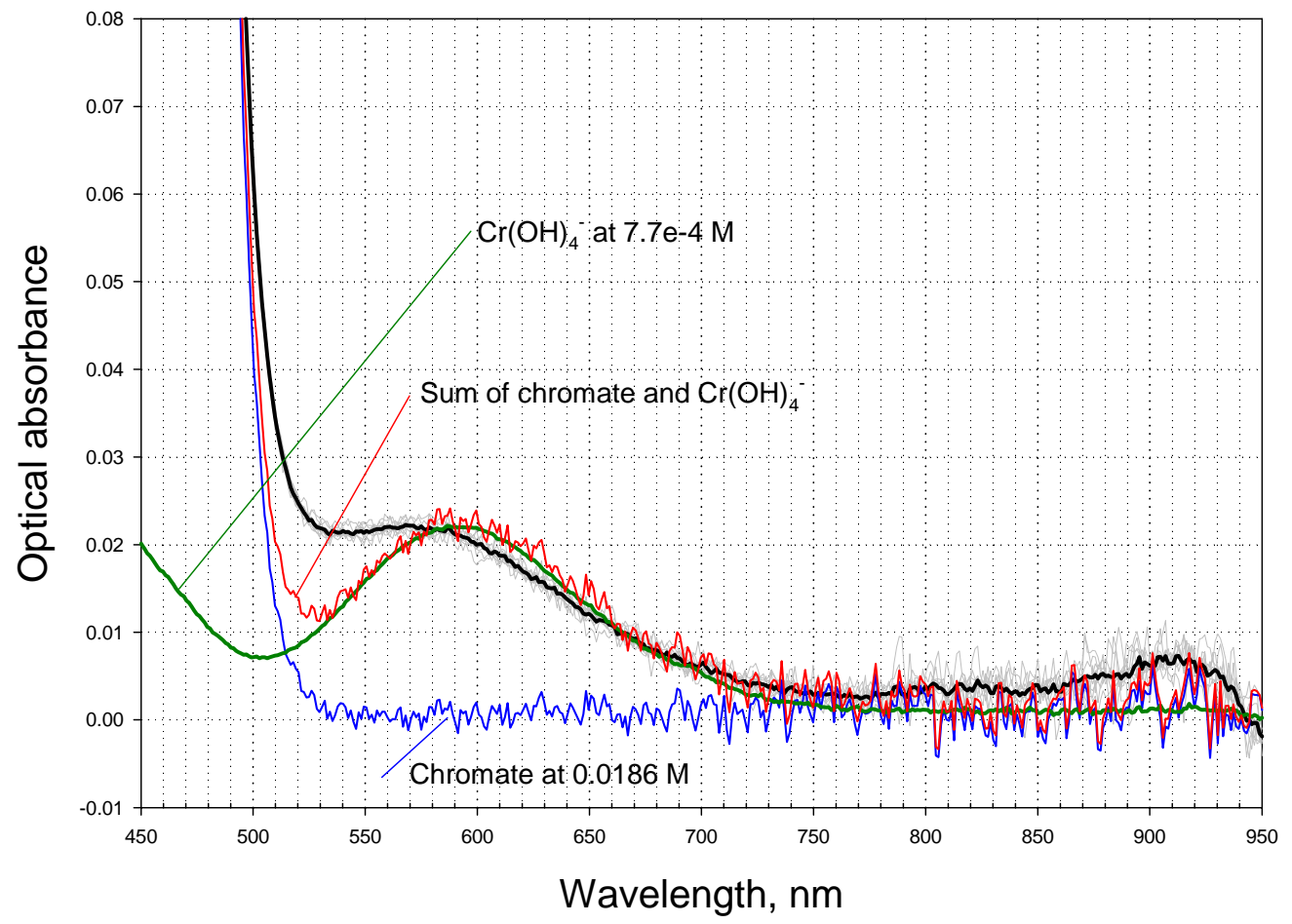

Figure 3.5. Spectral Feature Analysis with the Assumption that Chromate and Tetrahydroxochromium(III) Only Contribute to the Observed Spectrum

Two assumptions are available to explain this discrepancy: 1 ) the chromate spectra in pure $0.1 \mathrm{M} \mathrm{NaOH}$ solution and in the complex mixture of $2.7 \mathrm{M}$ of nitrate, $0.47 \mathrm{M}$ of nitrite, and a number of other inorganic and organic constituents are not identical, and they exhibit a more pronounced longer wavelength tailing effect in the latter case and 2) there is one more light-absorbing species, not associated with chromium, that manifests itself in the 540- to 700-nm range. Further experiments are needed to prove the validity of these assumptions. What is more important for a more realistic estimation of the $\mathrm{Cr}$ (III) concentration is that both assumptions imply that the optical absorbance at $570 \mathrm{~nm}$ is only partly associated with $\mathrm{Cr}(\mathrm{III})$ and, thus, its contribution to the total chromium concentration in the analyzed solution is significantly less that the upper limit of $4.5 \%$ obtained from the two-component analysis. 


\subsection{Conclusion}

In conclusion, the treatment of a filtered composite feed solution with IONSIV ${ }^{\circledR}$ IE-911 effectively reduced the ${ }^{137} \mathrm{Cs}$ concentration and so the radiation hazard associated with this dissolved saltcake composite. Little perturbation of any other major constituents was observed. Extensive physical, chemical, and radionuclide analyses were performed on the Cs-depleted feed solution. Some methods-development work was also performed for information purposes only using UV-visible spectroscopy to determine the concentrations of nitrate, nitrite, and the speciation of chromium between its +3 and +6 oxidation states. The results agree well for nitrate and nitrite (about a $10 \%$ discrepancy with the concentrations determined by ion chromatography). Agreement with the total concentration of chromium as determined by ICP-AES is excellent, with almost identical concentrations measured for both total chromium and chromate. This spectrophotometric method could be employed as an online monitor in the field to determine the behavior of nitrate, nitrite, and chromate during retrieval in real-time.

Speciation between chromium(III) and chromium(VI) indicates that $>95 \%$ of the chromium in this tank waste is as chromate, a result consistent with other studies on Hanford Site tank supernatants and leachate solutions. 


\subsection{References}

Brown GN, LA Bray, CD Carlson, KJ Carson, JR DesChane, RJ Elovich, FV Hoopes, DE Kurath, LL Nenninger, and PK Tanaka. 1996. Comparison of Organic and Inorganic Ion Exchangers for Removal of Cesium and Strontium from Simulated and Actual Hanford 241-AW-101 DSSF Tank Waste. PNL-10920, Pacific Northwest National Laboratory, Richland, WA.

Gasper KA, KD Boomer, ME Johnson, GW Reddick Jr, AF Choho, and JS Garfield. 2002.

Recommendation for Supplemental Technologies for Potential Mission Acceleration. RPP-11261 Rev. 0, CH2MHILL Hanford Group, Inc., Richland, WA.

Hamm LL, T Hang, DJ McCabe, and WD King. 2002. Preliminary Ion Exchange Modeling for Removal of Cesium from Hanford Waste Using Hydrous Crystalline Silicotitanate Material. WSRC-TR-200100400, Westinghouse Savannah River Company, Aiken, SC.

Rapko, BM and TG Levitskaia. 2003. Letter Report: Removal of ${ }^{137}$ Cs from Dissolved Hanford Tank Saltcake by Treatment with IE-911. TWS03.030, Pacific Northwest National Laboratory, Richland, Washington.

U.S. Department of Energy (DOE). 2002. Performance Management Plan for the Accelerated Cleanup of the Hanford Site (predecisional draft). DOE/RL-2002-47, Richland, WA. 


\section{Distribution}

No. of

Copies

ONSITE

$\underline{\text { DOE-Office of River Protection }}$

B. M. Mauss

13 CH2M HILL

K. D. Boomer

J. S. Garfield

K. A. Gasper

D. W. Hamilton

M. E. Johnson

Dennis Hamilton (5)

R. E. Raymond

G. W. Reddick, Jr.

R. D. Williamson

2 Fluor Hanford Inc.

W. S. Callaway

D. L. Herting
No. of

Copies

ONSITE

30 Pacific Northwest National Laboratory

L. M. Bagaasen (3)

K6-28

J. W. Brothers

K7-15

T. M. Brouns

K9-69

J. L. Buelt

P7-27

E. O. Jones

K6-24

G. B. Josephson

K6-69

T. G. Levitskaia

P7-25

G. J. Lumetta

P7-22

L. A. Mahoney

K7-15

B. P. McGrail

K6-81

B. M. Rapko (10)

P7-25

S. D. Rassat

K6-28

R. L. Russell

K6-24

R. J. Serne

P8-37

S. I, Sinkov

P7-25

J. S. Tixier

K6-24

J. D. Vienna

K6-24

Information Release (2)

K1-06

Distr. 1 